\title{
TAXATION WITHOUT INFORMATION: THE INSTITUTIONAL FOUNDATIONS OF MODERN TAX COLLECTION
}

\author{
Wei Cui*
}

ABSTRACT:

A prominent strand of recent economic and legal scholarship hypothesizes that third-party information reporting (TPIR) is essential to modern tax collection. The slogan, "no taxation without information," has captured researchers' imaginations and is even often presented as selfevident truth. This Article offers a fundamentally different perspective, arguing that the emphasis on TPIR is misplaced. TPIR is used largely in the collection of the personal income tax but not of many other types of modern taxes. Even for the personal income tax, TPIR also has close substitutes which do not involve information transmission to the government. Theoretically, appeals to TPIR are vitiated by the puzzle of payor compliance. And most purported empirical evidence for the effectiveness of TPIR fails to provide causal identification.

I suggest that to better understand the institutional foundations of modern tax collection, we should stop thinking of business firms as "fiscal intermediaries" in a game of deterrence against tax evaders. Instead, it would be more fruitful to conceive of firms as sites of social cooperation under the rule of law. The co-evolution of the business firm and modern regulatory law may have enabled modern governments to practice precisely "taxation without information."

\footnotetext{
* Author email: cui@allard.ubc.ca. I am grateful for comments on earlier drafts of the paper from Arthur Cockfield, Pierre-Pascal Gendron, Mitchell Kane, Michael Knoll, Leandra Lederman, Alan Macnaughton, George Yin, and audiences at the University of Toronto Law School James Hausman Tax Law \& Policy Workshop, University of Virginia Law School Fall Invitational Tax Symposium (2016), 109th National Tax Association Annual Meeting, and the Waterloo/Deloitte Tax Policy Research Symposium (2017). I am also grateful for discussion with Reuven Avi-Yonah, Jim Hines, Kyle Logue, Emily Satterthwaite, and Joel Slemrod. All errors remain my own. Copyright 2017 by Wei Cui. All rights reserved.
} 
INTRODUCTION

I. INFORMATION REPORTING: THE LINCHPIN OF MODERN

TAXATION?

II. INFORMATION REPORTING AS A DERIVATIVE INSTITUTION.. 106

A. The illusion of information transmission.........................107

B. The puzzle of payor compliance .....................................111

C. Lack of causal identification.............................................. 113

III. THE BOUNDARIES OF THIRD-PARTY REPORTING ...................115

A. Previous attempts at cost-benefit analyses of information reporting

B. Agency relationships, financial claims, and non-anonymity of transacting parties.

C. Recent evidence: Does credit card reporting increase compliance?

IV. FIRMS AS "FISCAL INTERMEDIARIES": AN INADEQUATE

CONCEPTION

V. FIRMS AS SITES OF SOCIAL COOPERATION ORDERED BY

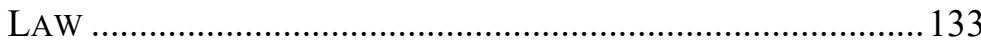

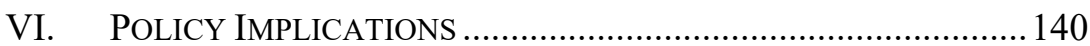

A. Implications for Developing Countries ..........................141

B. Implications for the U.S. and Other Developed Countries................................................................... 144

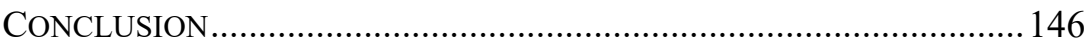

\section{INTRODUCTION}

Successfully raising tax revenue is a defining mark of the "state capacity" of advanced economies. ${ }^{1}$ Building effective tax administration is

1. See Timothy Besley \& Torsten Persson, The Origins of State Capacity: Property Rights, Taxation, and Politics, 99 AM. ECON. Rev. 1218, 1218 (2009) (commenting on state capacity to raise taxes) and sources cited in note 1 therein; Mark Dincecco, The Rise of Effective States in Europe, 75 J. ECON. Hist. 901 (2015) (explaining that "effective" states "have the extractive capacity to gather enough revenues, and the productive capacity to better channel public funds"). For the thesis that modern "state capacity" helps to explain the divergent paths of economic development of nations, see generally TIMOTHY BESLEY \& Torsten Persson, Pillars of Prosperity: The Political Economics of Development Clusters (2011) (explaining that economic development has long been attributed not just to rising incomes, but also to state effectiveness); Daron Acemoglu, Politics and Economics in Weak and Strong States, 52 J. MONETARY ECON. 1199 (2005) (summarizing that a weak state capacity and lack of taxation power can lead to the problems of less developed nations); Pranab Bardhan, State and Development: The Need for a Reappraisal of the Current Literature, 54 J. ECON. LIT. 862 (2016) (taking a broad look at the developmental goals of the state). 
one of the most urgent tasks facing the poorer countries of the world in their pursuit of sustainable development. ${ }^{2}$ These ideas have recently fueled extraordinary policy initiatives among many nations, as well as become the focus of cutting-edge research in political economy, public economics, economic history, and related branches of the social sciences. ${ }^{3}$ In 2015, the one hundred and ninety three United Nations (U.N.) Member States reached two comprehensive agreements, the Addis Ababa Action Agenda ${ }^{4}$ and the 2030 Agenda for Sustainable Development. ${ }^{5}$ Both agendas committed "to enhancing revenue administration through modernized, progressive tax systems, improved tax policy and more efficient tax collection. ... [and in particular to] strengthen international cooperation to support efforts to build capacity in developing countries...."6 A slew of major international projects were launched on the sidelines of the Addis Ababa Conference and in its aftermath, involving the coordination of international organizations that previously operated separately in this policy area. ${ }^{7}$ In the meantime,

2. See U.N., Addis Ababa Action Agenda of the Third International Conference on Financing for Development, U.N. DivisION FOR SuSTAINABLE DEV., https://sustainablede velopment.un.org/frameworks/addisababaactionagenda [hereinafter Addis Ababa Action] [https://perma.cc/WYH2-5LGF] (explaining that "significant additional domestic public resources.... will be critical to realizing sustainable development and achieving the sustainable development goals"). See generally, Michael Keen, Taxation and DevelopmentAgain (Int'l Monetary Fund, Working Paper 12/220, 2012) (explaining how tax and development issues have been a primary concern of the IMF); INT'L MONETARY FUND, Current Challenges in Revenue Mobilization: Improving Tax Compliance (2015), https://www.imf.org/external/np/pp/eng/2015/020215a.pdf [https://perma.cc/V4CA-RDTG] (stating that achieving tax compliance has been a priority for the developing world).

3. See, e.g., Timothy Besley \& Torsten Persson, Taxation and Development, in 5 HANDBOOK OF PUB. ECON. 51 (A. J. Auerbach et al. eds., 2013) (asking how countries move to raise a greater percentage of their GDP from taxes); Daron Acemoglu \& James A. Robinson, Why Did the West Extend the Franchise? Democracy, Inequality, and Growth in Historical Perspective, 115 Q. J. ECON. 1167 (2000) (looking at how extending voting rights relates to future wealth redistribution); Dincecco, supra note 1 (highlighting how tax collection leads to successful state development); Henrik J. Kleven et al., Why Can Modern Governments Tax So Much? An Agency Model of Firms as Fiscal Intermediaries, 83 ECONOMICA 219 (2016) [hereinafter KKS] (looking at how third party information reporting increases tax enforcement).

4. U.N., supra note 2.

5. U.N., Transforming our world: the 2030 Agenda for Sustainable Development, U.N. DIVISION FOR SUSTAINABLE DEV., https://sustainabledevelopment.un.org/post2015 /transformingourworld [https://perma.cc/8DER-NY9M].

6. U.N., supra note 2, art 2, 22.

7. For example, the Organization for Economic Cooperation and Development (OECD) and the United Nations Development Programme (UNDP) launched the Tax Inspectors Without Borders project to "help developing countries bolster domestic revenues by strengthening their tax audit capacities." Press Release, United Nations, Tax Inspectors without Borders: OECD and UNDP to Work with Developing Countries to Make Tax Audits More Effective (July 13, 2015). Moreover, the World Bank (WB) and International Monetary 
questions such as why developing countries tax so little and how developed countries can tax so much now draw the attention of some of the most innovative and influential social scientists. ${ }^{8}$ These intellectual developments can be seen as complementary to the global policy initiatives: if raising tax revenue is indeed crucial to the path to prosperity for all nations in the world, a framework for understanding the institutional foundations of modern tax collection is clearly in order.

Much of the recent, highly prominent social science research on the underpinnings of the tax collection capacity of advanced economies has converged on a simple, seemingly obvious line of reasoning. To collect tax, the government needs information about the taxable income, transactions, and other tax attributes of taxpayers. But the government is always in a situation of information asymmetry vis-à-vis taxpayers: the latter always have incentives to hide such information. The government's ability to overcome such information asymmetry therefore must be crucial for tax collection. And, scholars seem to believe, the most powerful way by which such asymmetry has been overcome is through third-party information

Fund (IMF) also launched a new initiative to help developing countries strengthen their tax systems. Press Release, Int'l Monetary Fund, World Bank and the IMF Launch Joint Initiative to Support Developing Countries in Strengthening Tax Systems, U.N. Press Release No. 15/330 (July 10, 2015), https://www.imf.org/en/News/Articles/2015/09/14/01/49/pr15330 [https://perma.cc/FP6C-6MJP]. The International Tax Compact launched The Addis Tax Initiative, in which over 30 countries and international organizations teamed up to strengthen international cooperation in strengthening tax administration, and in which participants commit to "collectively double their technical cooperation in the area of domestic revenue mobilisation and taxation by 2020." Press Release, Int'l Tax Compact, On the Occasion of the Launch of the ADDIS TAX INITIATIVE (July 15, 2015) (available at https://www.addistaxinitiative.net/documents/Addis-Tax-Initiative_Press-Release.pdf [https://perma.cc/X65U-MVKC]). In October 2016, the second meeting of the signatories of the Addis Tax Initiative was held in Paris, France. The meeting finalized the Work Plan for 2016/17, outlining the key priorities of the Addis Tax Initiative. Addis Tax Initiative, 2nd Meeting of the Signatories of the Addis Tax Initiative, Paris, France, AdDIS TAX InITIATIVE (Oct. 19, 2016), https://www.addistaxinitiative.net/\#slider-2 [https://perma.cc/5C46-7XSG]. More recently, the OECD, IMF, WB and U.N. announced "The Platform for Collaboration on Tax." See IMF ET AL., The Platform for Collaboration on Tax: Concept Note (Working Paper, 2016), https://www.imf.org/external/np/sec/pr/2016/pdf/pr16176.pdf [https:// perma.cc/T694-VBEP] (describing a new platform for international collaboration on tax issues). A report was prepared for the G20 Finance Ministers in the framework of the Platform for Collaboration on Tax. See IMF ET AL., ENhANCING THE EFFECTIVENESS of External Support in Building TAX CAPACity in Developing Countries (2016), http://www.oecd.org/tax/enhancing-the-effectiveness-of-external-support-in-building-taxcapacity-in-developing-countries.pdf [https://perma.cc/593W-JZ2K] (recommending ways countries can implement technical assistance programs and contribute funds for tax projects).

8. See, e.g., Timothy Besley \& Torsten Persson, Why Do Developing Countries Tax So Little?, 28 J. ECON. PerSP. 99 (2014); KKS, supra note 3; Henrik J. Kleven, How Can Scandinavians Tax So Much?, 28 J. ECON. PERSP. 77 (2014). 
reporting ("TPIR"). ${ }^{9}$ In the boldest formulation of this idea, Henrik Kleven, Claus Kreiner, and Emmanuel Saez claim that TPIR is a defining feature of modern taxation. ${ }^{10}$ In other words, mechanisms for transmitting taxpayer information to the government represent the institutional foundations of modern tax collection. To support this bold conjecture, a small but "rapidly growing" empirical literature ${ }^{11}$ has emerged that claims to offer novel evidence for the power of TPIR. ${ }^{12}$ The slogan, "no taxation without information," not only has captured researchers' imaginations but is often even presented as self-evident truth. ${ }^{13}$

Indeed, to many U.S. scholars and policymakers, this claim may seem quite familiar. U.S. policymakers, for example, have long been interested in narrowing the "tax gap," or the discrepancy between the tax revenue that is

9. As the author of one widely-cited study that purports to provide empirical support for this intuitive reasoning puts it:

A fundamental constraint for taxation is that governments need to be able to observe transactions in order to impose a tax on them. A growing literature therefore argues that understanding information flows is central to effective taxation. When governments imperfectly observe transactions, important differences emerge between forms of taxation that are equivalent in standard models of taxation but differ in the information they generate for the government. Third-party reporting, verifiable paper trails, and whistle-blowers are thought to play an important role in facilitating tax enforcement.

Dina Pomeranz, No Taxation without Information: Deterrence and Self-Enforcement in the Value Added Tax, 105 AM. ECON. REV. 2539, 2539 (2015) (citations omitted).

10. KKS, supra note 3, at 219. See infra Part I.

11. The description of this empirical literature as "rapidly growing" is borrowed from Joel Slemrod et al., Does Credit-Card Information Reporting Improve Small-Business Tax Compliance?, 149 J. PuB. ECON. 1-19, 2 (2017), discussed in detail in Part III infra. For a summary review, see Joel Slemrod, Tax Compliance and Enforcement: New Research and its Policy Implications 34-42s.3.3 (Ross Sch. Bus., Working Paper No. 1302, 2016) (summarizing various research on the evidence relating to third-party information gathering). For examples of some widely cited studies, see Carrillo et al., Dodging the Taxman: Firm Misreporting and Limits to Tax Enforcement, 9(2) AM. ECON. J.: APPLIED ECON. 144 (April 2017) (looking at the effects of non-credible tax enforcement when Ecuadorian firms were notified of revenue discrepancies); Henrik J. Kleven, et al., Unwilling or Unable to Cheat? Evidence from a Tax Audit Experiment in Denmark, 79 ECONOMETRICA 651 (2011) (analyzing a tax experiment where half the participants were audited and the rest were not); Pomeranz, supra note 9 (emphasizing the importance of gathering information to collecting taxes); Miguel Almunia \& David Lopez-Rodriguez, Under the Radar: The Effect of Monitoring Firms on Tax Compliance (Warwick Econ. Res., Paper Series No. 1070, 2015) (looking at the tax compliance effect from firm activity information trails); Joana Naritomi, Consumers as Tax Auditors (London Sch. Econ. \& Pol. Sci., Working Paper, 2016) (investigating the enforcement effect of the wider availability of third-party information gathering).

12. In this Article, I will use "information reporting," "third-party reporting," and "TPIR" interchangeably.

13. Pomeranz, supra note 9. 
collected and the revenue that ought to be collected. ${ }^{14}$ And greater information reporting has often been considered as a key approach to achieving this goal. ${ }^{15}$ Although whether the scope of information reporting should be expanded has been a matter of century-long debates, ${ }^{16}$ important legislative actions taken in 2008 have given greater emphasis to TPIR. ${ }^{17}$ Since 2011, the Internal Revenue Service (IRS) has required credit card companies and payment settlement entities such as eBay to report payments made to individuals and businesses. ${ }^{18}$ Financial institutions are also now under the obligation to furnish information about the tax basis of securities to taxpayers and the government to determine gains or losses on the sale of

14. See, e.g., Understanding the Tax Gap, IRS (Mar. 2005), https://www.irs.gov/new sroom/understanding-the-tax-gap [https://perma.cc/6N4M-NRA6] (last updated Sept. 27, 2017) (explaining the components of the tax gap).

15. Both the economic and legal literatures on tax compliance in the United States are very large and not possible to review here. For recent legal scholarship, see, e.g., Joseph Bankman, Eight Truths About Collecting Taxes from the Cash Economy, 117 TAX NOTES 506 (2007) (focusing on how the cash economy relates to the problem of the tax gap); Leandra Lederman, Reducing Information Gaps to Reduce the Tax Gap: When Is Information Reporting Warranted?, 78 FORDHAM L. REV. 1733 (2010) [hereinafter Lederman, Reducing Information Gaps] (proposing factors for evaluating information reporting requirements); Leandra Lederman, Statutory Speed Bumps: The Roles Third Parties Play in Tax Compliance, 60 Stan. L. REv. 695 (2007) [hereinafter Lederman, Statutory Speed Bumps] (arguing that tax law can and does promote compliance by implementing structural mechanisms such as withholding taxes).

16. See, e.g., Anuj C. Desai, What a History of Withholding Tells Us About The Relationship Between Statutes and Constitutional Law, 108 NW. U. L. REV. 859 (2014) (viewing the relationship between statutes and constitutional law from the angle of a statute that implemented tax withholding); Ajay K. Mehrotra, "From Contested Concept to Cornerstone of Administrative Practice": Social Learning and the Early History of U.S. Tax Withholding, 7 Colum. J. TAX. L. 144 (2016) (giving an overview of the development of tax withholding); Joseph J. Thorndike, Wall Street, Washington, and the Business of Information Reporting, 110 TAX NoTES 787 (Feb. 13, 2006), http://www.taxhistory.org/thp/readings. nsf/cf7c9c870b600b9585256df80075b9dd/a518ae7d8d5eaf23852571360068fc5e?opendocu ment [https://perma.cc/9VWH-Z9GR] (giving an overview of the history of tax information reporting in the U.S.).

17. See, e.g., Energy Improvement and Extension Act of 2008, Pub. L. No. 110-343, § 403, 122 Stat. 3765, 3854-58 (2008) (imposing additional reporting requirements on brokers for certain securities transactions); Housing and Economic Recovery Act of 2008, Pub. L. No. 110-289, § 3091(a), 122 Stat. 2654, 2908-11 (2008) (imposing an annual reporting requirement on payment settlement entities who make reportable payment transactions in a given calendar year).

18. I.R.C. $\$ 6050 W(2008)$. See infra Part III for a discussion of empirical literature analyzing the impact of credit card and third-party settlement entity reporting. See also, ShuYi Oei \& Diane M. Ring, The Tax Lives of Uber Drivers: Evidence from Internet Discussion Forums, 8 COLUM. J. TAX L. 56 (2017) (looking at Uber drivers' understandings of taxes and deductions). 
securities. ${ }^{19}$ Proposals to further expand TPIR continue to be advanced. ${ }^{20}$ Most importantly, the ever-expanding computing capacities of modern digital economies make the recording and transmission of transactional information to tax collectors easier and easier, which in turn seems to promise more effective government control of taxpayer information. ${ }^{21}$

This Article contributes to these vibrant intellectual and policy discussions by offering a fundamentally different perspective. Much recent scholarship, I argue, has mischaracterized the role of information reporting, which has also led to increasing confusions about the institutional basis of modern tax collection. To develop this perspective, I first engage in a debunking exercise, aimed at exposing weaknesses in the arguments and evidence adduced for the importance of TPIR. I show that TPIR is largely used in the collection of the personal income tax, and plays no role in most other types of modern taxes. ${ }^{22}$ Moreover, although information reporting and withholding are crucial to the collection of the personal income tax, to portray them as overcoming pre-existing information asymmetries between the government and taxpayers relies on legal artifices. ${ }^{23}$ I also show that the emphasis on TPIR fails to explain why payors specifically, and business organizations generally, would comply with the tax law. ${ }^{24}$ In particular, the prevalent belief that payor withholding or information reporting generates self-enforcing compliance dynamics is both practically unconvincing and theoretically naïve. Finally, most purported evidence for the effectiveness of TPIR is based on flawed empirical inferences. ${ }^{25}$

These de-bunking arguments demonstrate that TPIR cannot play the explanatory role that social scientists have assigned it: at least until the present, giving governments effective access to taxpayer information through third parties does not explain the success of modern tax administration. The arguments highlight previously neglected weaknesses in an apparent scholarly consensus: what many social scientists are increasingly coming to use as "stylized facts" (to motivate further theorizing and empirical work) actually involve grave misconceptions about the basis

19. I.R.C. $§ 6045(\mathrm{~g})(2015)$.

20. See, e.g., James Alm \& Jay A. Soled, Improving Tax Basis Reporting for Passthrough Entities, 143 TAX NOTES 809, 810 (May 19, 2014) (arguing that "the time has come to extend basis reporting beyond marketable securities and to require pass-through entities" to do the same).

21. Kleven, supra note 8, at 81 ("[T]he gradual transition from cash to credit card transactions may eventually eliminate most tax evasion even for self-employed individuals."); James Alm \& Jay A. Soled, W(h)ither the Tax Gap?, 92 WASH. L. REV. 521 (2017)

22. See infra Part I.

23. See infra Part II.A.

24. See infra Part II.B.

25. See infra Part II.C. 
of modern tax administration. This is the first major contribution of the Article.

In a second set of arguments, I articulate a new way of looking at the feasibility of TPIR, in terms of when information about the mutual identities of market participants is likely to be transmitted through market mechanisms. This perspective defines the limits of TPIR more sharply and parsimoniously than previous approaches, and suggests that TPIR will tend to be incomplete with respect to business income. ${ }^{26}$ I illustrate this perspective through an important recent study of the effect of TPIR by credit card companies on U.S. taxpayers, ${ }^{27}$ and, drawing on the same study, provide an explanation of how the incompleteness of TPIR renders it an ineffective tool in limiting tax evasion. ${ }^{28}$ This is the second major contribution of the Article.

Finally, I suggest that to better understand the institutional foundations of modern tax collection, we should stop thinking of business firms as "fiscal intermediaries" in a game of deterrence against tax evaders. Instead, it would be more fruitful to conceive of firms as sites of social cooperation under the rule of law. If firms enable social cooperation, but do so only with the support of a legal system, then compliance with law in business operations can often be expected. There need not be anything special about compliance with tax law in particular, and any valid explanation of why firms comply with the tax law is unlikely to be distinct from explanations of the phenomenon of business compliance with the law in general. ${ }^{29}$ I argue that this explanatory strategy is more consistent with the history of modern taxation - in particular, the fact that labor and workplace regulations were implemented well before the adoption of information reporting - than explaining tax compliance in terms of TPIR. The third major contribution of the Article is thus to put tax compliance into the context of business compliance with the law in general, and connecting both with the theory of the firm.

The Article proceeds as follows. Part I presents some important historical facts that have emboldened economists to hypothesize that TPIR is the linchpin of modern taxation. It then contrasts this bold hypothesis with a much more cautious view, which holds TPIR to be a derivative phenomenon. Part II offers a series of arguments for the latter view, identifying weaknesses in both the conceptual arguments and empirical evidence for the relevance of TPIR. Part III sets out a new theory about the limitation of information reporting, and shows how this theory is consistent

26. See infra Part III.A.

27. See infra Part III.B.

28. See infra Part III.C.

29. See Part V infra. 
with recent empirical evidence from the U.S. on the limited impact of TPIR. Parts IV and V then contrast the conceptions of firms as "fiscal intermediaries" and as sites of social cooperation. Part IV highlights the inadequacies of the former. Part V sketches out the latter conception and its promise both in terms of historical plausibility and theoretical coherence. Part VI briefly discusses some of the policy implications of the arguments in Parts I-V. A brief conclusion then follows.

\section{INFORMATION REPORTING: THE LINCHPIN OF MODERN TAXATION?}

Political economists who view taxation as a core component of modern state capacity emphasize that richer countries tax more, and any given country tends to tax more as it gets richer. ${ }^{30}$ In a recent, influential paper, Kleven, Kreiner and Saez (abbreviated below as "KKS") show that these patterns are driven entirely by countries' adoption of what they call "modern taxes." 31 They include in the definition of "modern taxes" personal and corporate income taxes, the value-added tax (VAT), and payroll taxes and social security contributions. ${ }^{32}$ By contrast, "traditional taxes" are defined as all other taxes, including property taxes, inheritance taxes, excise and sales taxes, custom duties, etc. ${ }^{33}$ Examining data from 2005 regarding 29 OECD countries and 43 non-OECD countries, they show that there exists a clear positive correlation between (i) GDP per capita and (ii) the ratio of revenue from modern taxes to GDP, but there is no correlation between GDP per capita and the ratio of revenue to GDP from traditional taxes ${ }^{34}$ (see Figure 1 below). Further, using data for 14 advanced economies over a 160 -year time horizon, they show that again, the growth in tax revenue in these countries over time is driven entirely by growth in "modern taxes," with no long-run increase (and typically a weak decline) in "traditional taxes" (see Figure 2 below).

30. Besley \& Persson, supra note 8, at 102; Besley \& Persson, supra note 3, at 56; KKS, supra note 3 , at 221 ; Kleven, supra note 8 , at 77-78.

31. KKS, supra note 3 , at 223.

32. Id.

33. Id.

34. See id. ("[T]he relationship between taxes and development across countries is driven by a stark variation in tax structure across countries.”) (emphasis in the original). 
Figure 1: Correlations between GDP and Revenue from "Modern" and "Traditional" Taxes ${ }^{35}$
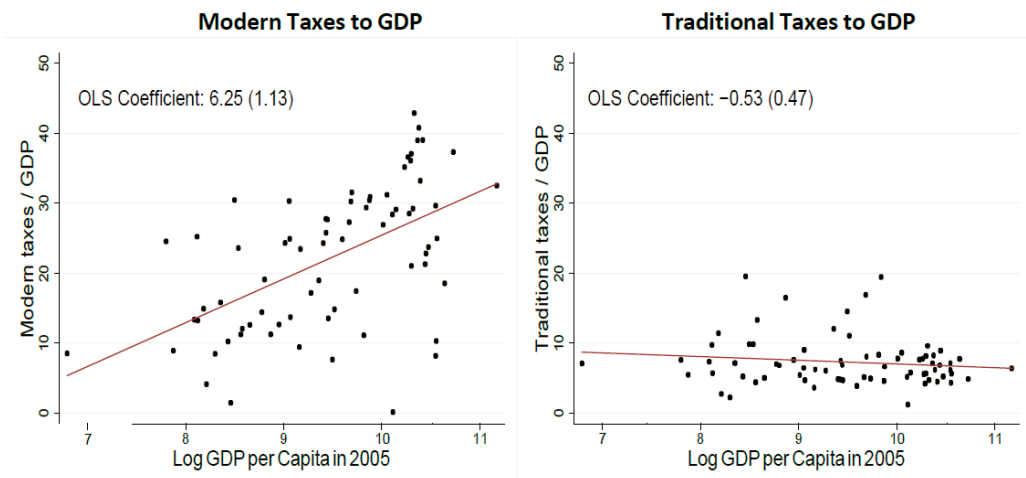

KKS offer an interpretation for these historical patterns that has gained great popularity among political economists studying tax administration. ${ }^{36}$ They postulate that in any country, the growth of tax revenue is constrained by the enforceability of taxes, which depends on the availability of taxpayer information to the government. ${ }^{37}$ All "modern taxes" are basically taxes in respect of which the "enforceability constraint" has been loosened or overcome, through the mechanism of "third-party reporting." ${ }^{38}$ By this latter term, KKS mean arrangements whereby firms act as intermediaries to collect information about other taxpayers and transmit such information to the government. ${ }^{39}$ They argue that when firms get sufficiently large, they are more likely to act reliably as such intermediaries, because the risk of firms' being caught cheating increases as firm size grows. $^{40}$ Therefore, roughly speaking, they present a picture where the growth of firm size in an economy causes "third-party reporting" to become more reliable, which in turn makes taxes more enforceable, and the optimal level of taxation more achievable.

That large firms tend to be more compliant with the tax law (and other types of law) is an important, but not uncommon, observation. ${ }^{41}$ What

35. Id. at 224

36. See sources cited supra note 11.

37. KKS, supra note 3, at 219-20.

38. Id.

39. This thesis is also advanced in Wojciech Kopczuk \& Joel Slemrod, Putting Firms into Optimal Tax Theory, 96 AM. ECON. REV. 130 (2006).

40. For a critique of this aspect of KKS, see infra Part IV.

41. See, e.g., Alm \& Soled, supra note 21, at 543-47 (observing that the workforce has concentrated in large firms, where tax compliance is high). KKS show, using recent data from 50 countries, that tax revenue and share of workforce in large firms are positively correlated across countries. KKS, supra note 3, at 225-26. 
KKS's theory adds to such observation is the contention that this matters for the capacity of governments to collect tax revenue because it helps solve a pre-existing problem of information asymmetry, i.e. the government's lack of information about ultimate taxpayers such as individual income-earners. ${ }^{42}$

Figure 2: Revenue Composition over Time for Select Countries ${ }^{43}$
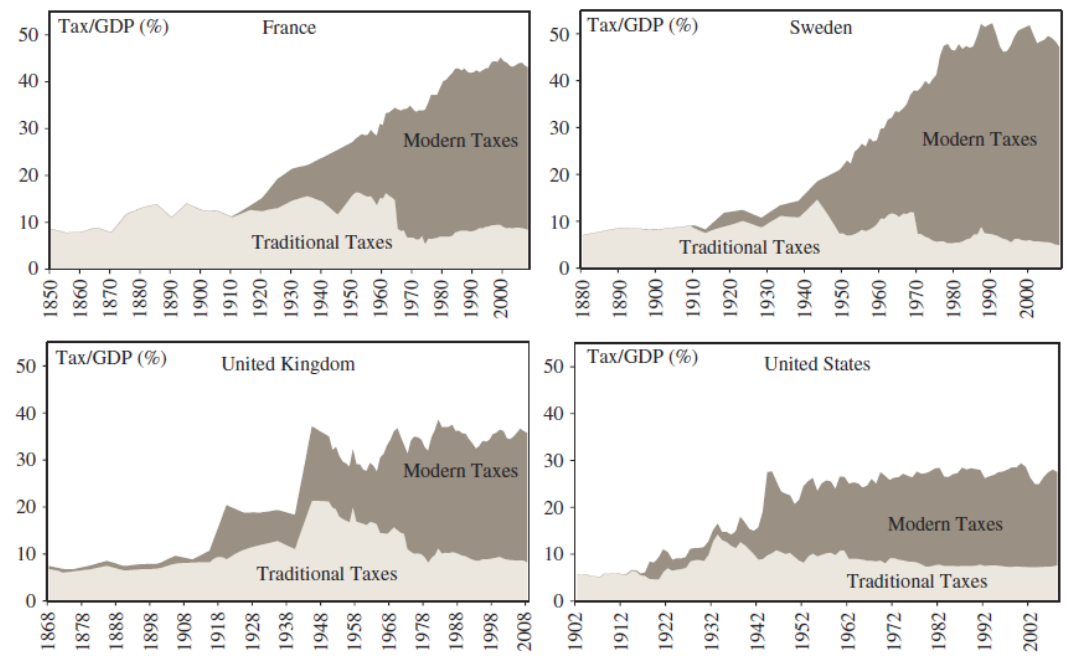

Other scholars have recently offered explanations of modern tax compliance in a similar spirit. That is, they first postulate information asymmetry as the most important kind of enforceability constraint for taxes, and then identify exogenously given types of economic development that relax such constraint. For example, Anders Jensen claims that because economically more developed countries have larger sectors of formal employment, they are able to make greater use of TPIR (with respect to wage income), and therefore more successfully overcome the information asymmetry vis-à-vis taxpayers. ${ }^{44}$ Roger Gordon and Wei Li argue that since tax collection depends on audits and the effectiveness of audits depends on

42. KKS also provide a theory of why large firms are more compliant that focuses on the increasing risk of being exposed by whistle-blowers. KKS, supra note 3, at 220. Part IV infra argues, on the contrary, that many other explanations may be at play and are much more relevant.

43. Id. at 225. KKS provide comparable historical information for other industrial economies in the Online Appendix to their article.

44. Anders Jensen, Employment Structure and the Rise of the Modern Tax System (Nov. 2015) (unpublished working paper) (available at https://www.tse-fr.eu/sites/default/f iles/TSE/documents/sem2016/jobmarket/jmp_jensen.pdf [https://perma.cc/2H57-PUQP]). 
the existence of paper trails, the level of development of a country's financial sector will substantially determine the country's capacity of tax collection. ${ }^{45}$

However, while the purported centrality of TPIR to modern tax compliance has become commonplace among many scholars, careful reflection suggests that the above evidence is actually consistent with opposite view, namely that the use of TPIR is quite limited in tax administration in advanced economies. To start, there is no obvious way in which the corporate income tax is enforced through TPIR. Corporations report income and deductions largely on the basis of their own accounting records. This is illustrated in the United States by regulatory rules that specifically exempt corporations from information reporting requirements that are applicable to payments to individuals: businesses that purchase services worth more than $\$ 600$ a year from a service provider generally need to report such payments to the IRS, but not if the provider is a corporation. ${ }^{46}$ The same corporate exemption applies to the payment of interest and dividends. ${ }^{47}$

The value added tax (VAT), which is a large source of revenue in most countries (although not in the U.S., which has not adopted a VAT), also does not involve information reporting. ${ }^{48}$ Under the VAT, firms - which are nominally the taxpayers - charge VAT on goods and services sold to other firms and to individuals, and firms engaged in businesses may claim tax credits for the VAT that they have been charged on input purchases. ${ }^{49}$ They then remit any net VAT amount - tax charged on sales minus input tax credits - to the government (hence the term "value added"). However, firms generally do not transmit information about payments to and specific transactions with vendors and customers to the government, but instead aggregate transaction information into lines on simple tax returns. ${ }^{50}$

45. Roger Gordon \& Wei Li, Tax Structures in Developing Countries: Many Puzzles and a Possible Explanation, 93 J. PUB. ECON. 855 (2009). Gordon and Li view financial institutions primarily as the depository of information to which the government may have access, rather than intermediaries that automatically transmit such information to the government. However, the literature on TPIR (cited in note 11 supra) has treated Gordon and Li's work as reaching kindred conclusions. See infra Part IV for a critique of conceptions of the firm both as intermediaries and as depositories of information.

46. Treas. Reg. $§ 1.6041-3(\mathrm{p})(1)(2017)$.

47. Treas. Reg. § 1.6049-4(c)(1)(ii)(A) (2017).

48. KKS acknowledge this point in an endnote, but refer to the fact that the VAT creates a paper trail. KKS, supra note 3, at 242-43 n.8. The existence of a paper trail does help audits, but it does not automatically provide the government with any information before an audit. Cf. Alm \& Soled 2016, supra note 21 (contrasting information reporting and audits).

49. See generally Alan Schenk et Al., Value Added TaX: A Comparative Approach 1-46 (2d ed. 2015) (giving a general overview and history of the VAT).

50. See generally id. at 92-186 (examining the supply chain and tax credits in the VAT context) 
The prevalence of TPIR is really most pronounced in the individual income tax context, and only for wage and passive investment income. U.S. workers, for example, receive W-2 forms each year from their employers regarding their wage income and the federal, state as well as social security taxes that have been withheld from such income. U.S. investors receive 1099 forms regarding their dividend, interest, capital gain, and certain other types of passive investment income. Social security and pension payments, which one can also think of as forms of passive investment income, are subject to TPIR as well. These types of income represent a very substantial portion of the U.S. individual income tax base, and therefore TPIR may appear to be thoroughly built into the tax. But, in reality, that is not the case. The practical and political difficulties of extending information reporting beyond the contexts of employment and passive investment income are wellknown. $^{51}$ The most important examples of information reporting outside these contexts are the long-standing requirement to report business payments made to independent contractors providing services, ${ }^{52}$ and the much more recent requirements for credit card companies and other payment settlement entities to report sales settled by non-cash means. ${ }^{53}$ The effectiveness of these two types of information reporting is still controversial; Part III infra will specifically review recent empirical evidence for the (in)effectiveness of credit-card reporting. But few would disagree that TPIR with respect to individual business income is largely incomplete. ${ }^{54}$

Overall, therefore, it is fair to say that TPIR is used very little in the corporate income tax, VAT, and the taxation of individual business income, while it is used with respect to an individual's wage and passive financial income. Even in the United States, which relies on the personal income tax for revenue to a much greater extent than other OECD countries, ${ }^{55}$ sales and property taxes and corporate income taxes (none of which generally relies

51. See sources cited in note 16 supra (describing the long and difficult process of how income tax withholding became accepted). See also, Joseph J. Thorndike, Do We Have a Tax Compliance Crisis in Washington?, TAX HISTORY PROJECT (2009) (calling for all politicians on Capitol Hill to release their tax returns); Joseph J. Thorndike, The Income Tax Is Inquisitorial-Get Over It, TAX ANALYSTS BLOG (Jan. 29, 2013), http://www.tax analysts.org/tax-analysts-blog/income-tax-inquisitorial-get-over-it/2013/01/29/168416

[https://perma.cc/L6B8-XEUT] (describing Italy's intrusive tax reporting measures and explaining that income tax collection has always been somewhat intrusive).

52. I.R.C. $\S 6041$ (a) (2017).

53. I.R.C. § 6050W (2017).

54. See Bankman, supra note 15 (analyzing the underreporting and underpaying of tax in the individual business sector); Carrillo et al., supra note 11 at 162 (concluding that some Ecuadorian firms in a study may have preferred to underreport costs and remain in the informal sector); Slemrod et al., supra note 11 (explaining that tax enforcement for small businesses is more challenging than for large firms).

55. OECD, Revenue Statistics 2016 - The United States (2016), available at https://www.oecd.org/tax/revenue-statistics-united-states.pdf [https://perma.cc/JV82-Q3PJ]. 
on TPIR) generate about $36 \%$ of total government revenue. ${ }^{56}$ Another $24 \%$ of total government revenue comprises social security contributions, and as discussed in Part II.A, at least half of this revenue (and maybe the entirety of it) can be characterized as not involving TPIR. ${ }^{57}$ Thus emphasizing TPIR seems to privilege, without obvious justification, (certain elements of) the individual income tax. A more neutral characterization seems to be that it is business organizations that play essential roles in collecting all modern taxes: they are intermediaries (third parties) in respect of several types of taxable individual income, but are taxpayers in their own right in respect both of taxable individual business income and of other taxes.

This, however, is not how scholars - not just economists but also legal scholars - have written about third-party reporting. ${ }^{58}$ The standard view is that, first, TPIR is crucial for tax collection on wage and passive financial income, and second, the practical limitations on third-party reporting for other types of (individual taxable) income may be overcome, when the cost of compliance can be sufficiently reduced. ${ }^{59}$ If this is correct, the present limitations of TPIR are a matter of mere detail, while the power of TPIR is the more basic "stylized fact" that is significant for social science.

In the following two Parts, I argue against this standard view in two ways. Part II argues that TPIR is a derivative component in modern tax administration. Part III offers an explanation of why information reporting would generally not work outside the wage and passive investment income context. The explanation implies that there are hard limits to the completeness of information reporting, which in turn constrains its utility.

\section{INFORMATION REPORTING AS A DERIVATIVE INSTITUTION}

To properly evaluate the significance of TPIR, three basic facts, to which the existing literature has given inadequate attention, must be taken into account. First, where it is applied in modern tax collection, TPIR often has close substitutes that would not support the claim that tax collection is conditioned on the transmission of taxpayer information to the government. ${ }^{60}$ These substitutes show that the dependence of taxation on information transmission is an illusion. ${ }^{61}$ Second, the appeal to TPIR leaves it mysterious why payors would comply with reporting obligations instead of colluding with payees. ${ }^{62}$ Third, although some evidence for the effectiveness of TPIR

56. Id. (computations based on 2013 and 2014 data).

57. See infra notes 67-71 and accompanying text.

58. See infra Part III.A for the discussion of legal scholars' views on TPIR.

59. See infra Part III.A for the discussion of legal scholars' views on TPIR.

60. See infra Part II.A.

61. See infra Part II.A.

62. See infra Part II.B. 
is routinely cited, none of such evidence identifies the causal effect of TPIR on compliance. $^{63}$

\section{A. The Illusion of Information Transmission}

The effective use of information reporting in the income tax context is observed mainly for wage and passive financial income. Reflection suggests that these components of the individual income tax base are distinctive in the following way: third parties - namely payors of wage, dividend, interest, etc. - possess both near-complete information about the specific items of income and control over their payment. ${ }^{64}$ But for any item of income such that there is a payor that possesses both complete information about it and control over its payment, information reporting is only one among several ways in which the government can collect tax.

One clear alternative is final withholding. For example, under the final withholding systems adopted in many European countries today, employers simply deduct tax from wage payments, and employees do not have to file income tax returns themselves. ${ }^{65}$ Similarly, banks paying interest and corporations distributing dividends simply withhold tax on interest and dividend payments at flat rates, without the need for individual taxpayers to report the receipt of such payments. ${ }^{66}$ Under final withholding, even though the recipients of income are nominally the taxpayers, they generally have no compliance obligations with respect to the income subject to withholding. Any information transmitted to the government simply helps the latter determine whether the payors have performed withholding correctly. In other words, third parties do not transmit information to the government in order to help the latter monitor the compliance of ultimate taxpayers.

There is in fact a more complete substitute for information reporting. For any item of income that could be subject to final withholding, an equivalent tax can be imposed simply as an excise tax on the payer. In the U.S., a contemporary example of this is the "social security taxes" imposed by the Federal Insurance Contributions Act (FICA) portion of the Internal Revenue Code. ${ }^{67}$ Under the FICA tax regime, taxes "with respect to

63. See infra Part II.C.

64. In Part II.D infra, I argue that it is specific economic conditions and legal conventions that enable the individual income tax base to be built from these types of income.

65. For a comparative review of the practice of final withholding on wage income and financial income, see U.S. DeP'T Treasury, ReP. To The Cong. ON RETURN-Free TAX Systems: Tax Simplification Is a Prerequisite (2003) [hereinafter Return-Free SYSTEMS] (conducting an examination of return-free systems in other countries).

66. Id. at $2,7$.

67. I.R.C. $\S \S 3101-3128$. 
employment" consist of an "excise" tax on employers ${ }^{68}$ and an "income" tax on employees, ${ }^{69}$ each of which is a percentage of the employees' wages. While the income tax on employees is required to "be collected by the employer of the taxpayer, by deducting the amount of the tax from the wages as and when paid," 70 the excise tax on employers is simply paid by employers themselves. However, from the perspectives of the employer and of the government, this distinction between the excise (employer) and withholding (employee) portions of Social Security contribution is merely nominal. They involve exactly the same calculations and remittance actions by the same parties, namely employers. ${ }^{71}$ It is also generally believed that they have the same economic incidence. ${ }^{72}$ Thus, although one can think of the withholding tax (the "employee portion") as involving the reporting by a third party (i.e., the employer) on the taxable wage of an ultimate taxpayer (i.e., the employee), this characterization would not be applicable to the excise tax that is administered in an identical fashion.

Indeed, the equivalence - from an enforcement perspective between a final withholding tax and an excise tax on the payor featured prominently in the history of the U.S. tax system. The first U.S. withholding tax, enacted by the 1862 Revenue Act, was applicable to (i) "the interest from railroad company bonds and the dividends from railroad company stock[,]" (ii) dividends paid by banks, trust companies, savings institutions, and insurance companies, and (iii) salaries of federal government employees in excess of 600 dollars per year. ${ }^{73}$ The nominal taxpayers for the tax - the persons on whom the tax was imposed - were the payors, not the recipients, of interest, dividends and salaries. ${ }^{74}$ Therefore, whether to label the 1862 tax an excise tax on payors or a withholding tax on payees is a choice involving little substance. ${ }^{75}$

Even more tellingly, the Civil War dividends tax led to the proposal in 1894 of the first corporate income tax: because in the nineteenth century corporations generally distributed most of their earnings as dividends, the

68. I.R.C. $\S \S 3111-3113$.

69. I.R.C. $\$ \S 3101-3102$.

70. I.R.C. $\S 3102$.

71. Desai, supra note 16 , at 894.

72. See Harvey Rosen \& Ted Geyer, Public Finance 314-15 (8th ed. 2007) (showing that excise and withholding portions of Social Security contribution have the same economic incidence).

73. Desai, supra note 16 , at 873-75.

74. Id. at 874. However, the payors of dividend and interest were " authorized and required" to " "deduct and withhold from all payments made . . the said duty or sum ...." Id. (emphasis in the original).

75. Because the nominal taxpayers were the payors themselves, the tax base of the withholding tax was not treated as part of the income of individual recipients. Id. at 875-76. 
corporate income tax was little different from a tax on dividends. ${ }^{76}$ The corporate income tax, that is, was a mutation from a withholding tax on dividends. Although one could think of the corporate income tax as involving information reporting on shareholders, it is uncommon to literally refer to it as such. ${ }^{77}$ But this point also works the other way: although one does not usually think of social security withholding on wage earners as an excise tax on the employer, one certainly could, just as the Internal Revenue Code explicitly labels the portion of FICA taxes imposed on employers. ${ }^{78}$

The underlying point is this: once a certain tax base is determined, whom the statute designates as the taxpayer, payor or recipient, is to a considerable extent a legal artifice. ${ }^{79}$ Where a "third party" possesses both complete information regarding an item of income belonging to the tax base and control over that item of income, then that third party can itself be made

76. See generally Steven A. Bank, From Sword to Shield: The Transformation of THE CORPORATE INCOME TAX, 1861 To PRESENT (2010); Desai, supra note 16, at 882, n.107 ("T] $\mathrm{The}$ tax on corporate income was simply the Civil War dividends tax in a new guise.... [T] he concept of 'withholding' of the stockholder's income tax at source had taken a small step toward the creation of a new and distinct concept: the corporate income tax.") (citation omitted).

77. Desai, supra note 16, at 882, n.107 ("Although there was a clear sense that taxing the income of an individual owner of shares at the corporate level was primarily grounded on the increased likelihood of collecting the tax, the idea that a corporate income tax was simply a 'withholding' of the shareholders' income eventually gave way.") (citation omitted).

78. I.R.C., supra note 68.

79. The equivalence between a withholding tax on the recipient of a payment and an excise tax on the payor is a well-known aspect of tax design and has many illustrations not only in the U.S. but also in the tax systems of other countries. A contemporary example of a tax on wage income imposed on employers is the Australian fringe benefits tax, imposed on employers for in-kind compensation for employees. Hugh J. Ault \& Brian J. ARnOld, Comparative Income Taxation: A Structural Analysis (3d ed. 2010), at Part II.B.1. Each of South Africa, Sweden, France, and Belgium has enacted taxes on corporations on their profit distributions that are the equivalent of withholding taxes on dividends. Juliana Benamran, France - Corporate Taxation $\S 6.1$, COUNTRY ANALYSES IBFD (July 21, 2016), https://online.ibfd.org/kbase/\#topic=doc\&url=/collections/cta/html/cta fr chaphead.html\& WT.z_nav=Navigation [https://perma.cc/VD5N-RB7E]. Gauthier Cruysmans, Belgium Corporate Taxation $\S 6.1$, COUNTRY ANALYSES IBFD (July 1, 2016), https://online.ibfd. org/kbase/\#topic $=$ doc\&url=/collections/cta/html/cta_be_chaphead.html\&WT.z_n av=Navigation [https://perma.cc/9W42-ADY5]. Johann Hattingh, South Africa-Corporate Taxation $\S$ 1.1.3, COUNTRY ANALYSES IBFD (June 1, 2016), https://online.ibfd.org $/ \mathrm{kbase} /$ \#topic $=$ doc\&url=/collections/cta/html/cta_za_chaphead.html\&WT.z_nav=Navigatio n [https://perma.cc/VXQ5-Y76K]. Emma Nilsson, Sweden - Corporate Taxation $\S 6.1$, COUNTRY ANALYSES IBFD (April 1, 2016), https://online.ibfd.org/kbase/\#topic=doc\&url= /collections/cta/html/cta_se_chaphead.html\&WT.z_nav=Navigation [https://perma.cc/R26EKK6Y]. Brazil has enacted excise taxes on payors of royalties to replace withholding taxes with respect to royalty recipients. Fernando Tonanni \& Bruno Gomes, Brazil - Corporate Taxation § 14.6.4., COUNTRY ANALYSES IBFD (March 1, 2016), https://online.ibfd .org/kbase/\#topic=doc\&url=/collections/cta/html/cta_br_chaphead.html\&WT.z_nav=Naviga tion [https://perma.cc/46EH-YDXD]. 
into the taxpayer with respect to such element of the tax base. There would be no need to provide information about a different taxpayer. If two taxes are enforced in the same way, but in terms of legal terminology there is a "third party" under one tax but no "third party" under the other tax, the "third party" aspect of the first way of enforcing tax is clearly superfluous.

Just as importantly, consider the question why a government would choose, in connection with any item of income, information reporting with respect to the recipient rather than excise taxation with respect to the payor. The answer is generally that there is some personal circumstance - be it progressive tax rates that depend on the recipient's total income (i.e., not just income from particular payments or payors), credits and deductions, personal expenses, and so on - to which the payors do not have easy access. ${ }^{80}$ Therefore, such private information would have to come from the recipients themselves. Insofar as such private information is not provided to the payors, excises or final withholding are not feasible, and accurate tax collection depends on compliance by the ultimate income recipients themselves. But this is just to say that the adoption of information reporting as opposed to withholding/excises is precisely premised upon the incompleteness of information possessed by payors (third parties). It is not a solution to the incompleteness of information held by the government.

This point has ample illustrations both historically and comparatively. In the history of U.S. taxation, for instance, there were no progressive tax rates for the withholding/excise tax mechanisms under the 1862 Revenue Act. ${ }^{81}$ Conversely, progressive income tax rates were introduced under the 1913 Income Tax Act, which rendered the withholding provisions of the Act infeasible, and information reporting replaced it. ${ }^{82} \mathrm{~A}$ comparative study carried out by the U.S. Treasury Department showed that the extent to which a country's income tax system takes into account individual taxpayer circumstances largely explains why some countries adopt final withholding for individual income while others do not. ${ }^{83}$

In sum, information reporting becomes relevant only when the tax law permits private information to be relevant. This undermines the pretense that there is some necessary, pre-existing information asymmetry - for example, between the recipients of wages, salaries, and dividends, on the one hand, and the government, on the other - which information reporting reduces or overcomes. Such asymmetry comes into place only when the government has made the choice of giving information - private to these

80. See generally RETURN-FrEe SySTEMS, supra note 65.

81. This was perceived to generate horizontal inequities among different taxpayers (because the income duty also imposed by the Act contained progressive tax rates through exemptions). Desai, supra note 16, at 876-78.

82. Id. at $884-88$

83. See generally RETURN-Free SyStEMS, supra note 65. 
recipients - policy significance. Information asymmetries and information reporting are two sides of the same coin.

\section{B. The Puzzle of Payor Compliance}

There is a different, more basic, reason why information reporting offers an inadequate explanation of compliance even in the context of taxing individual wage and financial income. An obvious question arises: what accounts for compliance on the part of the "third parties" that perform information reporting and/or withholding? What, for example, prevents employers from regularly colluding with employees in under-reporting wages, and bargaining with employees for the benefit of the tax savings from such underreporting ${ }^{84}$ Such collusion is widespread today in developing countries. ${ }^{85}$ It is also prevalent in the informal sectors in developed countries: in the U.S., for example, the level of compliance with the "nanny tax" is perceived to be low and has remained so for many years. ${ }^{86}$ It is in fact quite visible even in the formal sectors of developed countries: many employers and employees push the envelope on what counts as non-taxable fringe benefits, on the basis that the IRS is unlikely to conduct audits. ${ }^{87}$ Given that there are rarely other "third parties" monitoring the "third party" required to perform information reporting, why does the latter comply with tax law?

A typical answer given to this question is that employers can claim deductions for wage payments, which lower the employer's income tax liability. The employee and the employer thus have adverse interests, or opposing incentives, with respect to reporting wage payments: while the employee stands to lose from employer reporting, the employer gains from

84. See, e.g., Gideon Yaniv, Collaborated Employee-Employer Tax Evasion, 47 PuB. Fin. 312, 312 (1992) ("Under a tax withholding system, an employer and his employees may find it mutually beneficial to strike a bargain under which the former withholds less than the taxes due ... while the latter accepts less than the free market wage rate.").

85. For a recent study, see Todd J. Kumler et al., Enlisting Employees in Improving Payroll-Tax Compliance: Evidence from Mexico (Nat'l Bureau of Econ. Research, Working Paper No. 19385, 2013).

86. See Sue Shellenbarger, Family Secret: More Parents are Avoiding the Nanny Tax, Wall ST. J., Nov. 5, 2008, http://www.wsj.com/news/articles/SB122583716191498477 [https://perma.cc/MD37-HSTH] (explaining that the rise of the Internet has caused a lot of parents to stop paying the nanny tax); Celeste Watkins-Hayes, The Immorality of Evading the Nanny Tax, The ATLANTIC, Mar. 26, 2014, http://www.theatlantic.com/business/archive /2014/03/the-immorality-of-evading-the-nanny-tax/359637 [https://perma.cc/J48W-H6GN] ("Recent estimates suggest that fewer than 250,000 U.S. households report household employee wages, even though occupations like child care . . are growing ...").

87. Joseph Bankman ET AL., Federal InCOME TAXATION 426 (16th ed. 2012); Yaniv, supra note 84 , at 313 . 
it. Information reporting is therefore "self-enforcing." " It is also often assumed that this reasoning applies to other types of payments. ${ }^{89}$

While this answer may be plausible in certain contexts, it both lacks empirical generality and is theoretically naïve. In terms of empirical validity, the answer may seem to have appeal in the U.S., where personal income tax rates have been relatively low ${ }^{90}$ and the nominal corporate income tax rate high $^{91}$ since the 1960s. Therefore, employers' wage deductions may often save more tax dollars than the tax liabilities of employees. However, even in the U.S., there are many situations where payments of income taxable to payees are not deductible or generate minimal benefits to payors: examples include non-deductible payments such as dividends and personal expenditures (e.g. childcare), and deductible payments made by payors subject to low or zero effective tax rates (e.g., due to losses, accelerated depreciation, or tax exemptions). Indeed, it is generally believed that the effective tax rate of U.S. corporations is far lower than the nominal tax rate, ${ }^{92}$ and may well be lower than the individual income tax rate applicable to many employees. And in many OECD countries, the effective tax rate applicable to wage income (especially when payroll taxes or social security contributions are considered) far exceeds the corporate income tax rate applicable to employers. Therefore, the net potential tax saving from nonreporting of wage income is quite significant.

Generally, holding information reporting to be self-enforcing is theoretically naïve because it assumes that the parties to the transactions (both the party that must declare income and the party that claims expense

88. Lederman, Reducing Information Gaps, supra note 15, at 1739, 1747, 1751 n.93; Lederman, Statutory Speed Bumps, supra note 15, at 711, 729-30.

89. Payors are also subject to penalties for failing to withhold or report to the government. See InTERnal Revenue SERvice Pub. 55B, Data boOK 21 (2016) (Rev. 3-2017) (noting that " $[\mathrm{t}]$ he IRS audited $0.7 \%$ of all individual income tax returns filed in CY 2015 , and $1.1 \%$ of corporation income tax returns (excluding S corporation returns)"). However, with low audit rates, the expected value of such penalties may be very low. While there are far fewer employers than employees in any economy, the number of employers is generally still too great for tax authorities realistically to maintain a high rate of audit coverage. Indeed, the audit rate for parties required to perform information reporting is not known to be higher than in other areas of tax administration. Therefore, a high probability of detection through audits cannot be what explains payor compliance.

90. U.S. Federal Individual Income Tax Rates History, 1862-2013 (Nominal and Inflation-Adjusted Brackets), TAX FouND. (Oct. 13, 2013), https://taxfoundation.org/usfederal-individual-income-tax-rates-history-1913-2013-nominal-and-inflation-adjustedbrackets/ [https://perma.cc/T68N-2YEX].

91. Historical Corporate Top Tax Rate and Bracket: 1909-2014, TAX POL'Y CTR. (Dec. 2, 2015) http://www.taxpolicycenter.org/sites/default/files/legacy/taxfacts/content/pdf/corpo rate historical bracket.pdf [https://perma.cc/LS5C-NENV].

92. See Yaniv, supra note 84, at 315 (citing a study showing that in 1982, the average effective tax rate of U.S. corporations was $13.1 \%$ when the statutory tax rate was $46 \%$ ). 
deductions) are subject to similar effective tax rates. But when this is the case, the government precisely collects no net revenue from the transaction: the inclusion by the payee is cancelled by the deduction by the payor. ${ }^{93}$ It is when parties are not subject to the same tax rates that the government can collect net revenue from a transaction, but then, putting aside transaction costs and the failure to reach and maintain collusive bargains, the potential will always exist for the parties to collude and lower the net payment to the government. For instance, if an employer's corporate income tax rate is substantially higher than the personal income tax rate applicable to wage recipients, an incentive arises for employers and employees to collude to over-report wage payments.

This problem - the pervasive incentives for payor-payee collusion - is relevant even if final withholding, excise taxation, or any other alternative to information reporting is adopted. It is thus of fundamental significance in theorizing about compliance, and is taken seriously by theorists who rigorously model tax compliance. ${ }^{94}$

\section{Lack of Causal Identification}

The following fact is routinely touted as evidence for TPIR's effectiveness in securing compliance. In the U.S. and a number of other countries, tax administrators study the "tax gap" by conducting audits designed to precisely measure the compliance level of a representative sample of the population. ${ }^{95}$ Many of these studies have revealed that the taxpayer compliance rate is much higher for wages and passive financial income than it is for self-employment income. ${ }^{96}$ Since wage and passive financial income are usually subject to TPIR while self-employment income is not, it is argued, higher compliance is produced by TPIR. ${ }^{97}$

93. In other words, the irony of "self-enforcing" mechanisms is that the government can never expect to raise any net revenue where they operate.

94. See, e.g., KKS, supra note 3, at 219-24 (analyzing collusion as it pertains to compliance); Yaniv, supra note 84 (highlighting the impact of collusion).

95. Kleven et al., supra note 11; Mark D. Phillips, Individual Income Tax Compliance and Information Reporting: What Do the U.S. Data Show? 67 Natl TAX J. 531, 536 (2014).

96. Kleven, supra note 8, at 79-83; Kleven et al., supra note 11, at 653; Phillips, supra note 95, at 532; Internal Revenue Service, U.S. DeP'T Of Treasury, Pub. No. 3744 (Rev. 6-2014), StRATEGIC Plan FY2014-2017 34 (2014), https://www.irs.gov/pub/irs-pdf/p3 744.pdf [https://perma.cc/64DR-DYUP]; InTERnal ReVEnUE SERVICE., U.S. DeP'T OF TReasury, TAX GaP Estimates FOR TAX YeArs 2008-2010 5 (Apr. 2016), https://www.irs.gov/pub/newsroom/tax\%20gap\%20estimates $\% 20$ for $\% 202008 \% 20$ through $\%$ 202010.pdf [https://perma.cc/5SHF-AKN7].

97. See Joel Slemrod, Cheating Ourselves: The Economics of Tax Evasion, 21 J. Econ. PeRSP. 25, 37 (2007) ("Line item by line item, there is a clear positive correlation between the rate of compliance and the presence of enforcement mechanisms such as information reports and employer withholding."). 
Such inferences from correlation to causation are, however, highly unreliable. Specifically, it is rarely possible to disentangle the use of TPIR from two types of confounding factors, which may undermine both the internal and external validity of the inferences. These two factors are (a) the nature of the (individual) income and (b) the nature of the payor.

Consider the first. As suggested in Part II.A supra (and as will be further elaborated in Part III infra), TPIR seems particularly tailored to wage and passive investment income. Yet, governments can often secure compliance with tax collection with respect to these types of income without relying on TPIR. For example, most financial transactions create paper (or digital) trails, and such documentation trails, as opposed to TPIR, may induce compliance with respect to passive financial income. None of the studies purportedly demonstrating the effectiveness of TPIR, however, try to distinguish the effect of TPIR from the effect of paper trails. Yet the distinction is important: a paper trail is useful only if the government decides to audit taxpayers, while TPIR itself would affect the making of that decision.

Similarly, as argued earlier, tax can be effectively collected from wages and financial income through withholding or, equivalently administratively, payor excise taxation. There has been no study to show that TPIR is more effective than withholding or excise taxation (or, where withholding and information reporting are simultaneously implemented, that the latter is effective independently of the former). This implies that no evidence has been produced that "but for" TPIR, the level of compliance could not be as high as is actually observed. ${ }^{98}$

Consider next the nature of the payor. In one study analyzing Danish taxpayer data, Henrik Kleven and co-authors found that after controlling for both whether an item of income is subject to TPIR and whether it is likely to be audited, the effect of firm size still has a significant impact on the rate of tax evasion. ${ }^{99}$ They infer from this that "collusion between taxpayers and third parties may be important in small firms," even in Denmark. ${ }^{100}$ This suggests that firm size may matter for compliance independently of the use of TPIR. By contrast, there has been no study investigating the distinct effect of TPIR while holding firm size constant. ${ }^{101}$

98. Contrast this with the claim made in Kleven, supra note 8 , at 79 , that it has been shown "empirically that tax enforcement is successful if and only if third-party information covers a large fraction of taxable income" (emphasis added).

99. Kleven et al., supra note 11 , at 676.

100. Id. at 676 n.27.

101. This is no doubt partly due to the fact that the main studies testing the effectiveness of TPIR are based on individual taxpayer returns, and therefore, can typically control only for the characteristics of the individual taxpayers. See sources cited supra note 96. 
Purported evidence for TPIR's effectiveness that is not based on individual tax return data is even more problematic. For example, some point to the fact that economies with larger formal employment sectors have higher tax-to-GDP ratios. ${ }^{102}$ Yet, these are likely to be economies with greater presence of large firms, which are responsible for paying for the bulk of wages. ${ }^{103}$ The compliance of such firms, as opposed to TPIR per se, may be the reason for the high level of observed compliance with respect to wage income. The fact that much tax revenue is collected through taxes not involving TPIR further weakens the credibility of claims about TPIR's relevance. ${ }^{104}$

If there is causation in this area, it is more plausible to regard it as lying between the large tax base of wages and financial income in advanced economies, on the one hand, and the collection of revenue from such income, on the other. When a large wage and financial income tax base is absent, information reporting could have little use. But once such conventions are developed, other collection mechanisms, such as final withholding or payor excise taxation, may be deployed instead of information reporting. The differences among these different collection mechanisms do not map onto differences in enforcement and are merely nominal. Therefore, the "third party" aspect of information reporting cannot constitute genuine causal mechanism.

\section{THE BOUNDARIES OF THIRD-PARTY REPORTING}

Scholars who hold information reporting to be essential to modern tax compliance also tend to express great optimism in information reporting's future. ${ }^{105}$ To them, the benefits of information reporting are proven, and its cost can only go down. ${ }^{106}$ So far, I have questioned whether information reporting's benefits have really been proven. In this Part, I suggest a new way of thinking about how the cost of TPIR determines its limits, i.e., why we find third-party reporting in some places and not others. Moreover, I discuss some strong evidence of the ineffectiveness of TPIR beyond its traditional spheres.

102. See, e.g., Kleven, supra note 8 , at 81-83 (pointing to such a fact).

103. Jensen, supra note 44.

104. See supra Part I.

105. See, e.g., Alm \& Soled, supra note 21 (providing an example of scholars who believe information reporting is beneficial). See also Pomeranz, supra note 9, at 2567 ("[M]echanis $\mathrm{ms}$ that provide information to the government, such as online billing systems or electronic receipts ... may have high returns.").

106. Id. 


\section{A. Previous Attempts at Cost-Benefit Analyses of Information reporting}

Legal scholars have previously attempted to articulate a framework for analyzing the costs and benefits of third-party reporting. ${ }^{107}$ Yet, the predictive power of what they have suggested is limited. For example, Leandra Lederman has described six conditions: ${ }^{108}$

a) The party furnishing the information report should be at arm'slength from, and should be unlikely to benefit from collusion with, the taxpayer.

b) Only those who possess a bookkeeping infrastructure should be required to information report.

c) Information reporting parties should be fewer in number than taxpayers reported on, allowing the government to centralize the sources of information.

d) "Information reporting is most effective when it provides all of the information necessary for the government to match the third-party report with corresponding amounts on the taxpayer's return; partial reporting reduces enforcement efficiency."

e) There should be few ways for the taxpayer to cheaply avoid information reporting.

f) Transactions that do not contribute substantially to the tax gap in the absence of information reporting should not be prime targets for information reporting.

It is not hard to see that the predictive power of these six factors is weak. Consider the idea that parties furnishing the information report should be unlikely to benefit from collusion. ${ }^{109}$ In reality, the potential for collusion among employers and employees to evade taxes (and for similar collusion among other arm's-length parties) is ever present. ${ }^{110}$ Nonetheless, this has not precluded employer information reporting from being adopted. Similarly, it is true that those required to information report generally possess a bookkeeping infrastructure and are fewer in number than taxpayers reported on. But these two factors are equally present in contexts where third-party reporting is generally not adopted. Supermarkets and department stores possess bookkeeping infrastructures and are fewer in number than individual shoppers. Yet governments do not require retail stores to report the individual purchases made by shoppers (although stores may be asked to collect sales taxes). Finally, the principles that there should be limited

107. See, e.g., Lederman, Reducing Information Gaps, supra note 15. See also Bankman, supra note 15.

108. Lederman, Reducing Information Gaps, supra note 15, at 1739-41.

109. Id.

110. See discussion infra Part II.B (explaining payor compliance challenges). 
opportunities for cheap avoidance, and that TPIR's costs should be commensurate with its benefits, clearly apply to legal design in general, and do not specifically explain the scope of third-party reporting.

Factor (d) on Professor Lederman's list, however, does imply a way of predicting the use of information reporting. When there is discrepancy between gross payment and taxable income, information reporting by the payor needs to be structured to reconcile such discrepancies to be useful. For example, when brokers were only required to report proceeds from sales of securities to the IRS, without reporting the tax basis of the securities in respect of their owners, the information reported was only of limited utility. ${ }^{111}$ The requirement commencing in 2011 for brokers to report on the tax basis of securities thus illustrates a change from incomplete to more complete reporting on capital gain and loss. ${ }^{112}$ Conversely, as we will see through the extended discussion of recent credit card reporting in the U.S. below, ${ }^{113}$ when discrepancies between gross payment and taxable income cannot be reconciled, the utility of information reporting for the government is sharply reduced. ${ }^{114}$

Other scholars have also noted the need for information reporting to be complete to be effective. ${ }^{115}$ However, when is information reporting likely to be incomplete? Little attention has been given to answering this question. I will now suggest an answer: information reporting is likely to be incomplete whenever the income-generating activity involves many market transactions from which agency relationships and financial claims are absent.

111. See Lederman, Reducing Information Gaps, supra note 15, at 1743-44 ("Accordingly, this change will likely prove to be a valuable one.").

112. See id. at 1743 (explaining that the Emergency Economic Stabilization Act of 2008 enabled comprehensive reporting on securities sales).

113. See discussion infra Part III Section C.

114. See id. (discussing how information reporting may still serve purposes other than transmitting information to the government).

115. See Bankman, supra note 15, at 513 ("One problem with this sort of scale-back is that as the proportion of transactions subject to third-party reporting declines, the utility of each item reported also declines."); Carrillo et al., supra note 11, at 162 ("In addition, the effect of third-party reporting can be limited when such reporting is incomplete and the tax authority has limited ability to audit the unreported margins."); Slemrod et al., supra note 11, at 19 ("For information reporting to have a strong effect on tax compliance, it must target a noncompliant group of taxpayers and it must subject a large share of their income to information reporting."). 


\section{B. Agency Relationships, Financial Claims, and Non-Anonymity of Transacting Parties}

It appears that all instances of TPIR in the individual income taxation context involve either: (i) a relationship of agency, (ii) a contractual relationship, especially one establishing a financial claim, or (iii) a combination of the two. For example, employment is an agency relationship. Financial income typically arises from financial claims, though in modern financial markets financial claims tend to be intermediated by layers of agency relationships. ${ }^{116}$

Market transactions involving agency relationships and financial clams are distinctive in the following respect: they require mutual knowledge of the identities of the transacting parties. ${ }^{117}$ It is the intrinsic nature of an agency relationship for the principal and agent to know who each other are. Similarly, financial claims by definition persist over time; therefore, the parties need the identities of their counterparties to locate them later on. Thus, parties that have financial claims against one another generally do not remain anonymous. ${ }^{118}$ By contrast, the sale and purchase of goods and services generally transpire in such a way that parties need not know the identities of their counterparties, or in any case do not retain information about such identities. Transactions in goods and services require the keeping of identities only insofar as they create claims over time (e.g., warranty for defective products) or the relationship of agency.

The distinctiveness of agency relationships and financial transactions in terms of the keeping of party identities has, to my knowledge, seldom been noted. ${ }^{119}$ It is, however, related to the claims that law and economics scholars have made about the contexts in which parties make enforceable contracts. Polinsky and Shavell, for example, suggest that contracts are first needed in "virtually any kind of financial arrangement." 120

116. For a recent discussion in the tax literature of such relationships, see Reid Thompson \& David Weisbach, Attributes of Ownership, 67 TAX L. REV. 249 (2014).

117. Government transfers such as low-income support or supplemental income for the unemployed, which are often subject to information reporting and/or withholding, are also inherently non-anonymous. Some agency relationships and financial claims may nonetheless involve anonymity (e.g., the use of bearer instruments). So one may think of the presence of agency relationships and financial claims as generally necessary but not sufficient conditions for the keeping of mutual identities.

118. Where they do, they are connected through a chain of non-anonymous agency relationships

119. See Wei Cui, Destination-Based Cash-Flow Taxation: A Critical Appraisal, 67 U. Toronto LAw J. 301 (2017), Part VI, where I explore the implications of this phenomenon for the structure of international taxation.

120. Mitchell Polinsky \& Steven Shavell, Economic Analysis of Law, in THE New Palgrave Dictionary of Economics (Steven N. Durlauf \& Lawrence E. Blume eds., 2d ed. 
For similar reasons, they suggest that parties make enforceable contracts to arrange "the supply of customized or specialized goods and services, which cannot be purchased on a spot market in a simultaneous exchange for money."121

The presence of agency relationships or financial claims predicts the boundaries of information reporting remarkably well. In the U.S., most types of information reporting are done by parties in agency relationships or subject to financial claims. Reporting by employers and brokers are examples of the former; reporting by payors of interest, dividends, social security payments, and by partnerships and S-corporations are examples of the latter. Recently introduced reporting by payment settlement entities, such as Visa, and third-party settlement entities, such as eBay, ${ }^{122}$ can be viewed as based on both agency and financial relationships. The major deviation from reporting by principals, agents, and parties subject to financial claims is reporting by businesses of payments to service providers of annual amounts in excess of $\$ 600$ (i.e., the issuance of 1099-MISC forms). ${ }^{123}$ Even here, the limitation of information reporting to recipients of services (as opposed to goods) requires rationalization, which is easily suggested by the fact that most such services involve either an agency relationship or at least something very close.

The connection between agency and financial transactions, on the one hand, and information reporting, on the other, is straightforward. In such transactions, market participants routinely record payments made to identified parties. All the government has to do in imposing reporting requirements is to harness such information. By contrast, in other transactions where parties do not normally keep track of mutual identities, obtaining information about such identities and associating transactions with them introduces costs not originally present in market activities. It is this kind of cost that policymakers may not find justifiable to impose, especially when the information gathered would offer only an incomplete picture of the tax base.

A good illustration of this point is a third-party reporting device that has received frequent favorable comments from academics in recent years,

2005), at 14. This is presumably because such arrangements inherently require performance in the future.

121. Id. Indeed, the relationship of contract itself perhaps always implies non-anonymity between the contracting parties. But non-anonymity may extend to agency relationships without contract. And while there may be many instances of non-agency, non-financial contracts, the absence of payment under such contracts (until the time of performance) may render them less relevant for income tax purposes. Hence the claim here that information reporting always involves agency relationships and financial transactions can be seen as an adaptation of Polinsky and Shavell's general claim to the tax context.

122. See infra Part III Section C.

123. Treas. Reg. $\S 1.6041-1$. 
but is perceived to deliver only very mixed results in the real world: inducing consumers to report on merchants through the use of lotteries. ${ }^{124}$ Generally, we do not expect merchants to keep information about consumers, for reasons just noted. Suppose, however, that a lottery is established, so that consumers who report enough of their receipts from purchases may win a prize. Such a system was implemented in Sao Paolo, Brazil. ${ }^{125}$ To facilitate the lottery, merchants collected social security numbers from consumers, and such information was later used for processing lottery claims. ${ }^{126}$ It is clear here that it was the lottery - a type of financial transaction ${ }^{127}$ — that created the need of merchants to collect consumer information. By contrast, if we ask how often merchants (i.e., sellers of ordinary goods and services) need social security numbers from their customers, the answer is almost never. ${ }^{128}$

Within the income tax context, the logic of agency relationships and financial claims helps to explain the scope of information reporting in two ways. First, if income can be computed only after taking deductions into account, and if either income, deductions, or both arise from activities involving multiple market transactions, information reporting by payors is likely to require identity-keeping by market participants who would otherwise not keep mutual identities. The additional social cost of gathering

124. For favorable academic comments on consumer lotteries in information reporting, see, e.g., Bankman, supra note 15, at 510-11 (noting that lotteries are cheap compliance measures); Lederman, Reducing Information Gaps, supra note 15, at 1753 ("A creative alternative used in some countries is to have consumers' receipts double as lottery tickets."); Slemrod, supra note 11, at 39-40 (explaining how lotteries incentivize consumers to report firm tax evasion); and Joana Naritomi, Consumers as Tax Auditors 35 (London Sch. of Econ. and Political Sci., Working Paper, 2016) ("In particular, the paper provides supporting evidence that consumers respond to lottery incentives to ask for receipts, which is the most common policy reward used by governments to mobilize consumers against tax evasion."). For critical discussion of real-world experience, see, e.g., IMF, supra note 2, at 29-30 (highlighting the limits of lottery schemes); Jonas Fooken et al., Improving VAT Compliance-Random Rewards for Tax Compliance 3 (Eur. Comm'n Taxation Papers, Working Paper No. 51-2014, 2014) ("While there is growing interest in the use of tax lotteries throughout Europe, the understanding of best practises [sic] and success factors is still limited.").

125. Naritomi, supra note 124 , at 11.

126. Id. at 11-15.

127. Many consumer lotteries aimed at improving tax collection involve instantaneous lotteries, and thus, simply give incentives to consumers to help create paper trails (e.g., sales receipts) as opposed to actually involving them in information reporting. See Fooken, supra note 124 (documenting insights from a workshop that sought to bring together countries with experience and those interested in running tax lotteries).

128. Consumers may voluntarily keep information about merchants (for purposes of returns, warranties, etc.), but requiring information reporting by consumers on merchants would be something different. It would also violate the conditions of centralization and bookkeeping infrastructure that Lederman identified. Lederman, Reducing Information Gaps, supra note 15. 
and transmitting transactional information would be hard to justify, especially if even the aggregate of the transactions may not correctly reflect income (given the difference between cash and accrual accounting, between ordinary and capital expenditures, and so on).

Second, agency relationships and relationships of financial claims explain the imposition of information reporting requirements even where the transactional amounts do not closely track the tax base, i.e., despite the likely ineffectiveness of information reporting. U.S. broker information reporting of gross receipts from the disposition of securities before the recent introduction of basis reporting is an example of this. The filing of forms 1099-MISC and 1099-K is another. Here, the adoption of information reporting can be rationalized at least by its relatively low cost - the government is merely harnessing information that market participants already possess.

In summary, TPIR is likely to be adopted only where the incremental cost of gathering transaction information (including identities of transacting parties) is small relative to business practices in the absence of tax, and especially if the additional cost of transmitting such information is matched by a distinct benefit for the government in identifying the tax base. Modern economic conditions and income tax law have molded a large portion of the individual income tax base to fit these conditions, but much of the rest of the tax base of "modern taxes" has never come close to meeting these conditions. I believe this account constitutes a more parsimonious description of patterns in the actual use of information reporting than previous accounts. Identifying such a systematic pattern should make the effective scope of information reporting less of an article of faith.

\section{Recent Evidence: Does Credit Card Reporting Increase Compliance?}

The theory just advanced is consistent with the very mixed evidence for the effectiveness of TPIR when implemented beyond the realm of wage and financial income. A uniquely authoritative study on this topic was carried out recently by economists at the IRS and the University of Michigan. ${ }^{129}$ Slemrod et al. examined how self-employed individual taxpayers (Schedule C filers) in the U.S. responded to information reporting newly introduced in 2011. Under the new reporting regime, electronic payments received by businesses (e.g., credit card payments and payments by online commerce platforms such as eBay) are reported by the firms processing these payments. ${ }^{130}$ This enabled the researchers to carry out a

129. Slemrod et al., supra note 11.

130. See Money Crashers, What Online Resellers Need to Know About the 1099-K, U.S. 
large-scale study: Slemrod et al. matched 2.5 million new information returns (1099-Ks) filed in 2012 to the tax returns of over a million Schedule C filers. ${ }^{131}$

At first glance, the IRS' capacity to analyze such a large quantity of information may bolster one's confidence that TPIR would help detect and deter non-compliance. However, Slemrod et al.'s study suggests three sobering conclusions. First, the new information reporting regime has not detectably increased taxpayer compliance. Second, the data that the IRS possesses about individuals' business income even under the post-2011 regime is very incomplete and noisy. And third, although careful econometric analyses establish instances of taxpayers' strategic behavior in response to information reporting, the nature of the strategic behaviors detected is difficult to interpret; the data analysis thus does not yield clear audit implications.

1. 1099-K reporting: incompleteness and minimal deterrence effect

Slemrod et al. first found that at least in the first two years (201112), the introduction of Form 1099-K had no impact on the aggregate net income reported by Schedule $\mathrm{C}$ filers. ${ }^{132}$ There was also no detectable additional deterrence effect relative to pre-existing information reporting. ${ }^{133}$ They concluded that the overall initial deterrence effect of the new form of reporting was minimal. ${ }^{134}$ Rather, the main impact of the introduction of Form 1099-K discovered by their study was on a small group of taxpayers representing less than ten percent of their sample; the characters and behavior of this group are further discussed below. ${ }^{135}$ But before turning to such specific findings, it is important to reflect on Slemrod et al.'s finding of

NEWS \& WORLD REPORT (Apr. 10, 2012, 9:00 AM), https://money.usnews.com/money/blogs /my-money/2012/04/10/what-online-resellers-need-to-know-about-the-1099-k

[https://perma.cc/687Z-4CZR]; Kelly Phillips Erb, Credit Cards, The IRS, Form 1099-K And The \$19,399 Reporting Hole, FORBES (Aug. 29, 2014, 11:13 AM), https://www.forbes.com/ sites/kellyphillipserb/2014/08/29/credit-cards-the-irs-form-1099-k-and-the-19399-reportinghole/\#4337ff851ae8 [https://perma.cc/2JZL-9CQQ] (explaining the intricacies of new reporting requirements that became effective in 2012).

131. Slemrod et al., supra note 11 , at 7 . These information returns represented $\$ 160$ billion (three percent) of the total $\$ 5.3$ trillion of receipts reported to the IRS on all 10.3 million 1099-Ks through the new information reporting program.

132. Id. at 11 .

133. Id. at 7-10. The revenue growth for taxpayers who became subject to information reporting for the first time under 1099-K followed similar trends, on average, to other groups of taxpayers already subject to prior information reporting (e.g. using 1099-MISC). The trends are also similar for the group of taxpayers not subject to either type of reporting. Id. at 12 .

134. Id. at 12 .

135. See Part III.C.2 infra. 
minimal deterrence on the overall population. This seems disappointing, especially to those who had advocated for the adoption of credit card reporting. Whatever social costs were incurred in the preparation and issuance of 1099-K forms, it appears that no new revenue was raised. ${ }^{136}$

This result can be explained in a number of ways. For instance, the most common type of tax evasion is done through cash transactions anyway. ${ }^{137}$ But perhaps equally importantly, even if one disregards taxmotivated uses of cash, one might be concerned that the scope of credit card reporting is insufficiently broad. Slemrod et al.'s data suggests that for those taxpayers subject to $1099-\mathrm{K}$ reporting, more than $85 \%$ reported receipts that were significantly greater than the amounts shown on the 1099-Ks they received - indeed, most taxpayers reported far more - and only fewer than five percent reported significantly less. ${ }^{138}$ Under Slemrod et al.'s theoretical assumptions, in the absence of information reporting, taxpayers who are predisposed to cheat will under-report business receipts. When there is information reporting, these taxpayers may believe that failing to declare at least the amounts of receipts reported on Form 1099-Ks substantially and discontinuously increases the risk of audit. Therefore, such taxpayers would report amounts on their Schedule C's that are at least equal to amounts reported on 1099-Ks. In other words, information reporting creates a floor for reported receipts. When this idea is applied to the real world, however, it appears that this floor was binding only for about ten percent of the Schedule C filer population. ${ }^{139}$

This is consistent with the idea that for most businesses, a substantial gap may exist between the volume of all market transactions and the volume of transactions for which the parties maintain mutual identities. Indeed, this idea is the basis for the main analytical strategy of Slemrod et al.'s study. They assume that amounts reported on Form 1099-Ks will accurately represent the total business receipts only for a very small segment of taxpayers, e.g., online sellers who derive most of their receipts from the likes of eBay, etc. ${ }^{140}$ Based on this assumption, they hypothesize that among those taxpayers whose reported receipts on Schedule C closely match amounts reported on Form 1099-Ks, a substantial portion will be taxpayers with "a high propensity to under-report receipts prior to the introduction of

136. Slemrod et al., supra note 11, at 7-10.

137. Id. at 1-2.

138. Id. at 8 (Figure 2); correspondence with Joel Slemrod and Daniel Reck. "Significantly" greater or less here means amounts either five percent greater or five percent less than the amounts reported on the relevant 1099-Ks.

139. Id. at 10.

140. Id. at 2 ("Bunching may occur because firms believe that reporting receipts above the 1099-K amount avoids triggering an audit by contradicting third-party information, or because all or virtually all of a firm's receipts are subjected to credit-card information reporting (as may be the case with exclusively online businesses)."). 
information reporting ...."141 In other words, rather than seeing amounts reported on Form 1099-Ks as setting a relevant benchmark for truthful reporting, close matching between Schedule C and 1099-K receipts should be seen as a potential sign of cheating.

This methodology stands the traditional conception of the benefits of information reporting (e.g., in connection with wage and passive financial income) on its head. Under the traditional paradigm, third-party payors provide near-complete information about taxable income to the government, such that taxpayers are "unable to cheat" on such income. ${ }^{142}$ For credit card reporting, however, third-party information may be so incomplete in respect of both taxable receipts and deductible expenses that two consequences inevitably follow. First, credit card reporting may leave plenty of room for the under-statement of taxable receipts for taxpayers whose receipts far exceed the amounts subject to 1099-K reporting. Second, even if credit card reporting forces some taxpayers to report more taxable receipts than they would have reported otherwise, they are not thereby "disabled" from cheating, because they can still fudge numbers on the deductions side. This second consequence is illustrated by Slemrod et al.'s finding of taxpayer strategic behavior.

\section{Strategic behavior in response to information reporting}

Slemrod et al. postulate that credit card reporting would force some taxpayers to report more taxable receipts than they would otherwise. ${ }^{143}$ But two other types of related behavior are also likely. First, these taxpayers may report amounts on their Schedule C's not much more than, and possibly exactly equal to, amounts reported on 1099-Ks. Second, they may increase reported expenses to offset increased reported receipts, because it is more difficult to verify expenses than to verify receipts. When information reporting is incomplete, third-party-reported amounts may set a useful floor for reported receipts, but they do not provide a useful ceiling for reported expenses. Overall, then, Slemrod et al. imply that if one observes taxpayers who (i) file tax returns only when subject to information reporting, (ii) whose self-declared receipts largely match third-party reported receipts, and/or (iii) whose expenses closely match receipts, such patterns are potentially indicative of a propensity towards tax evasion.

Motivated by such reasoning, Slemrod et al. focused on the $9-10 \%$ of their taxpayer sample that reported gross receipts within five percent of the gross amount on the 1099-K's issued to them. This is the group of

141. Id. at 2 .

142. Kleven et al., supra note 11, at 651-52.

143. Slemrod et al., supra note 11, at 4. 
taxpayers that "bunched" around the point where the ratio of (i) the receipts reported on 1099-K forms issued to the taxpayer (denoted "K") to (ii) gross receipts reported on a taxpayer's Schedule C (denoted " $R$ ") is $1 .{ }^{144}$ Slemrod et al. observe that taxpayers with $\mathrm{K} / \mathrm{R}$ close to 1 report unusually large increases in receipts from 2010 to 2011, which cannot be explained by the trend of growth of taxpayers that happen to have a high share of true receipts subject to information reporting. Instead, it is likely that many taxpayers with $\mathrm{K} / \mathrm{R}$ close to 1 reported more receipts after becoming subject to additional third-party reporting.

Slemrod et al. find several other types of evidence of taxpayer strategic behavior. First, taxpayers with $\mathrm{K} / \mathrm{R}$ close to 1 in 2011 were substantially less likely to have filed a Schedule $\mathrm{C}$ in prior years. ${ }^{145}$ Second, taxpayers bunching around $\mathrm{K} / \mathrm{R}=1$ also reported large increases in expenses, which to a great extent offset the increases in reported receipts by this group, resulting in little change in net income reported. ${ }^{146}$ Third, taxpayers bunching at where $\mathrm{K} / \mathrm{R}=1$ and new Schedule $\mathrm{C}$ filers who also receive 1099Ks are disproportionately likely to also bunch around the point where the ratio of reported expense to receipt is $1 .{ }^{147}$ Fourth and finally, the authors examine the composition of expenses to see precisely where taxpayers increased expense reporting to offset increased receipts reporting, and find increases occurred primarily in the "Other Expenses" line item. ${ }^{148}$ In other words, the new reported expenses seem opaque in their nature.

It seems likely, therefore, that some of the "bunching" taxpayers are cheating. The group of taxpayers showing the foregoing "suspect" patterns amounts to about one percent of the total population of taxpayers that the authors studied. ${ }^{149}$ This suggests a potential benefit of TPIR for improving the IRS' audit strategies, despite the overall finding that U.S. credit card reporting has not yet improved taxpayer compliance. ${ }^{150}$ If one thinks of the IRS's task of enforcing the law on Schedule C filers as searching for the proverbial needle in the haystack, the new regime, it might be suggested, has

144. "Bunching" means an abnormal concentration of taxpayers at a point relative to the overall distribution of taxpayers along a given dimension. However, not all taxpayers that bunch around $\mathrm{K} / \mathrm{R}=1$ deserve suspicion. Some taxpayers may simply have a high share of true receipts subjected to information reporting. If they report truthfully, their reported receipts should largely match third-party reported receipts. Slemrod et al. confirm the presence of such taxpayers. Slemrod et al., supra note 11, at 15.

145. This is the "extensive margin" response to 1099-K. The authors conservatively estimate that Form $1099-\mathrm{K}$ caused more than $20 \%$ of taxpayers in this particular group to start filing Schedule C's. Id. at 12.

146. Id. at 10-18.

147. Id. at 10 .

148. Id. at 17.

149. Correspondence with Joel Slemrod and Daniel Reck.

150. Slemrod et al., supra note 11, at 15-17. 
the potential of both reducing the size of the haystack and also increasing the size of the needle. It reduces the size of the haystack by getting the IRS to focus on the "bunchers": 1099-K reporting gives the IRS a specific target group to direct its limited enforcement resources. It also enlarges the size of the needle by revealing taxpayers' strategic behavior, such as new Schedule $\mathrm{C}$ filing, increased claims of expenses, and matching claims of increased expenses and receipts. Information reporting, in other words, may generate footprints for the IRS to follow. ${ }^{151}$

However, this optimistic view faces at least two objections. First, unlike taxpayers who under-declare wage income compared to amounts reported on their W-2s, many "bunchers" displaying "suspect" revenue and expense patterns may not be cheating. There are other, benign reasons why taxpayers may have increased receipt reporting (including by filing Schedule $\mathrm{C}$ for the first time) in response to information reporting, while simultaneously increasing reported expenses. ${ }^{152}$ Therefore audits of this taxpayer population will need to pick out the "needles" from the irrelevant, "needle-like" items. ${ }^{153}$ Second, Slemrod et al. find that the "bunching" taxpayers tend to be significantly smaller than the typical 1099-K recipients. ${ }^{154}$ The revenue potential for devoting audit resources to this group is thus limited, and may compare unfavorably with the option of auditing larger taxpayers. In other words, focusing on "bunchers" does not so much reduce the size of the haystack as to direct the IRS to an arbitrarilydetermined corner of it. Therefore, it is not clear that credit card information

151. I am grateful to George Yin for discussions of this point.

152. First, prior to information reporting, some taxpayers may have skipped reporting the portion of their total receipts that corresponded to business expenses. The prior failure to report thus represents a form of what one might call "self-help tax code simplification." Second, many payments reported by credit card companies may not represent true business receipts because of fees, taxes, and merchandise returns. Some taxpayers may have tried to reconcile such discrepancies between amounts on information returns and true receipts by reporting fees, taxes, and merchandise returns as "other expenses." Third, the tax law may impose limitations on business deductions so as to "quarantine" them to particular types of income. Greater income earned in such quarantined activities would automatically (and legitimately) increase deductible expenses. Slemrod et al. offer persuasive evidence that this third reason does not explain the increase in expense reporting by the "bunching" taxpayers they study. Slemrod et al., supra note 11, at 15 n.32. However, the extent to which the two explanations given in the text underlie the increased expense reporting that they identify is unknown. Because Slemrod et al.'s formal model does not predict the complete offset of increased reported receipts by expenses even for strategic taxpayers, these explanations remain relevant.

153. Moreover, if the IRS is determined to search in this corner of the haystack, then tax cheats may avoid coming into it: the only taxpayers remaining would be the ones who are innocent. This means that the IRS may not be able to commit to auditing this portion of the taxpayer population.

154. Id. at 11 . 
reporting will lead to superior audit strategies. Its potential at generating deterrence is similarly unclear.

The foregoing critique is not meant to imply that the adoption of 1099-K reporting in the U.S. cannot have beneficial effects for U.S. tax administration. But it does suggest a general conclusion about the limitations of the TPIR's utility, given its limited implementability. This limitation has two aspects. Suppose that, for the reasons given in Part III.B, TPIR requirements may be implementable only for a fraction of market transactions. Suppose that this fraction is $\beta$. Then, first, if for many taxpayers, the proportion of transactions they are disposed to report $(\alpha)$ without TPIR is a higher proportion (i.e., $\alpha>\beta$ ), then TPIR will have no effect on the compliance behavior of these taxpayers. ${ }^{155}$ This is so, even if $\alpha$ may be significantly less than 1. Second, when the coverage of TPIR is incrementally raised, some taxpayers may be forced to increase reporting their taxable receipts, while engaging in related strategic behavior. It is not clear, however, that the IRS should audit such taxpayers, because audit selection may be based not on how low $\alpha$ is, but on how likely it is that an audit will result in significant adjustments. This depends not only on $\alpha$ but also the size of the taxpayer. ${ }^{156}$

\section{FIRMS AS "FISCAL INTERMEDIARIES": AN INADEQUATE CONCEPTION}

Previous scholars postulate that third-party reporting is an essential tax collection device that explains modern tax compliance and the capacity of developed countries to raise high levels of revenue. ${ }^{157}$ By contrast, I have portrayed third-party reporting as a derivative institution, incapable of explaining tax compliance by business firms and frequently substituted by other administrative devices in the history of modern taxation. Similarly, whereas many scholars view the scope of TPIR as affording indefinite expansion in the future, ${ }^{158}$ I argue that TPIR is characterized by definite limits. Nonetheless, I believe one fact that previous scholars have identified

155. Thus $1099-\mathrm{K}$ reporting may have no effect on the $85 \%$ of Schedule $\mathrm{C}$ filers for whom the K/R ratio is much smaller than 1 . See supra notes 116 and 119 and accompanying text. For another example, sole proprietors in the U.S. on average may report only $50 \%$ of their business income. See I.R.S., TAX GAP Estimates For TAX YeArs 2008-2010, supra note 96. But the coverage of TPIR $(\beta)$ may well be below this percentage for many taxpayers.

156. Suppose that taxpayers have total receipts of $R_{i}$ but only report a portion $\alpha_{i}$. Tax agencies may be mainly interested in those with the largest $R_{i}^{*}\left(1-\alpha_{i}\right)$, not the ones with the largest $\left(1-\alpha_{\mathrm{i}}\right)$.

157. See, e.g., KKS, supra note 3; Kleven, supra note 8; Pomeranz, supra note 9 (emphasizing the importance of third party reporting in tax collection).

158. See, e.g., Alm \& Soled, supra note 21; Carrillo et al., supra note 11 (touting the boundless benefits of TPIR). 
may still hold the key to understanding modern tax collection: namely, the centrality of business firms to the administration of modern taxes, be it the withholding of individual income and payroll, or retail sales taxes, or the payment of the corporate income tax, the VAT, and other business taxes. ${ }^{159}$ The main question, I would argue, is how to conceptualize the causal connection between firms and tax compliance.

The prevailing view of the role of firms in tax compliance is that they act as "fiscal intermediaries": they collect and remit taxes, as well as provide information about other taxpayers, to the government. ${ }^{160}$ Firms generate tax-related information to the government in two ways. First, by providing information directly to the government about the taxable income and taxable transactions of employers, investors, and customers, they preclude the possibility of not reporting such income or transactions by the latter taxpayers. Second, firms maintain accounting and transaction records, which represent information that is not automatically transmitted to the government but which the government may use in conducting audits. ${ }^{161}$ Through both mechanisms, firms act as depositories of accurate taxpayer information which the government can access. This substantially increases the probability of detection of non-compliant behavior, sometimes to close to $100 \%$. It therefore dramatically improves the deterrence effect of penalties on non-compliance.

This conception of firms as passive depositories as well as mechanical intermediaries of transactional information is, to my knowledge, unusual in legal and social scientific scholarship outside the study of taxation. It is often explicitly tied to the classic deterrence theory of tax compliance, pioneered by Allingham and Sandmo. ${ }^{162}$ Under the Allingham and Sandmo model, a taxpayer decides whether to engage in tax evasion by weighing the expected benefits of evasion against the expected cost of being

159. See supra Part I.

160. See, e.g., Richard Bird, Why Tax Corporations? 10 (Dep't of Fin. Can., Technical Committee on Business Tax'n Working Papers No. 1996-02, 1996), https://www.ecn.ulaval .ca/ sgor/cit/bird_FinanceCanadaWP_1996/whytaxcorps.pdf [https://perma.cc/EZG8-3YA $\mathrm{H}$ ] ("The key to effective taxation is information, and the key to information in the modern economy is the corporation."); KKS, supra note 3 (describing firms as fiscal intermediaries); Kopczuk \& Slemrod, supra note 39, at 130 (explaining that firms remit the majority of tax revenues to the government and are "often required to file information reports that can facilitate monitoring of tax liabilities").

161. See, e.g., Gordon \& Li, supra note 45, at $856 \mathrm{n.13}$ ("[G]overnments ... rely on accounting reports ... to double-check ... reports by firms on individual earnings ...."); KKS, supra note 3, at 220 ("[S] uch [accounting and transaction] records are widely used within the firm ...."); Pomeranz, supra note 9, at 2543 (describing how a firm's book of purchases leads to a third-party paper trail and explaining that although Chilean firms need not report that information to the tax authority, it can be accessed through an audit).

162. Michael G. Allingham \& Agnar Sandmo, Income Tax Evasion: A Theoretical Analysis, 1 J. Public ECON. 323 (1972). 
caught and penalized. ${ }^{163}$ Taxpayers comply when the expected disutility of evasion, which depends on the probability of detection and the magnitude of penalties, outweighs its expected utility. ${ }^{164}$ It has been widely observed that by itself, this simple model of the choice about whether to evade taxes seems unable to explain the high level of tax compliance observed at least in developed countries: the actual levels of penalties, audits, and evasion detected during audits in real life are all far too low to lead a rational individual considering only these factors to decide against tax evasion. ${ }^{165}$ Nonetheless, scholars have suggested that the Allingham and Sandmo model can be salvaged if one considers the role of business firms. ${ }^{166}$ When firms both automatically provide information to the government and maintain information relevant to audits, then the probability of detection of tax evasion (conditional upon an audit being carried out) is increased. ${ }^{167}$ Moreover, when there are fewer firms than individual taxpayers, the audit rate for firms is higher than for individuals, which also increases the probability of detection. ${ }^{168}$

Yet as our earlier discussion anticipated, ${ }^{169}$ this effort to reconcile the Allingham and Sandmo model with the observed high levels of tax compliance in the real world merely begs a further question: why do decision-makers in firms - owners, managers, and employers - choose not to evade tax? Why do they provide accurate information about other

163. Id. at 324-26.

164. Id.

165. See James Andreoni et al., Tax Compliance, 36 J. ECON. LiT. 818, 855 (1998) ("The most significant discrepancy that has been documented between the standard economic model of compliance and real-world compliance behavior is that the theoretical model greatly overpredicts noncompliance."); Leandra Lederman, The Interplay Between Norms and Enforcement in Tax Compliance, 64 OHIO State L.J. 1453, 1457 (2003) ("[I]t is often stated in the tax compliance literature that deterrence does not explain voluntary compliance levels in the United States or elsewhere."); Joel Slemrod \& Shlomo Yitzhaki, Tax Avoidance, Evasion and Administration, in 3 HANDBOOK OF PUBLIC ECONOMICS 1423, 1431 (A.J. Auerbach \& M. Feldstein eds., 2002) ("[B]ased on the degree of risk aversion exhibited in other situations people should be evading [taxes] a lot more than they apparently do."). For information on actual rates of audit, see INTERNAL REVENUE SERVICES, PUB. 55B, DATA BOOK (2015) (Rev. 3-2016), https://www.irs.gov/pub/irs-soi/15databk.pdf [https://perma.cc/E2KGB5DK] (providing information on rates of audit).

166. See KKS, supra note 3, at 241 (claiming that "third-party information reporting by employers can sustain tax enforcement in spite of low fines and low audit rates[,]" and that modeling information reporting in the firm context "overcomes the main shortcoming of the standard Allingham-Sandmo model of tax evasion"); Kopczuk \& Slemrod, supra note 39, at 133-34 (advocating "putting firms into optimal tax theory" because "firms ... give rise to relatively easy-to-monitor transactions and can minimize the number of private agents authorities must deal with").

167. Pomeranz, supra note 9, at 2540, 2545.

168. Kopczuk \& Slemrod, supra note 35, at 134; Pomeranz, supra note 9, at 2542.

169. See supra Part II.A. 
taxpayers to the government? In most countries, the population of firms is still large relative to the number of tax auditors, which means that the general probability of detection of tax evasion by firms would still be very low. Is there any device that renders firms intent on evasion "unable to cheat"? If not, then the Allingham and Sandmo model still cannot be reconciled with the levels of (firm) tax compliance observed in the world. Something else must explain observed firm compliance.

One of the latest attempts to solve this puzzle is found in the KKS study mentioned in Part I. ${ }^{170}$ KKS analyze a firm's "decision" not to evade tax as the feasibility for employers and employees to maintain an equilibrium of collusion: if everyone in the firm can agree to and honor a bargain to cheat on the taxes that the firm is required to remit, and to divide up the firms' consequent cash savings, then the firm will evade taxes. ${ }^{171}$ They argue that such equilibrium would be difficult to maintain under two types of circumstances. First, individual disgruntled (or morally conscientious) employees create a small probability that the collusion would be reported and detected, and such probabilities would become sufficiently large when the firm is sufficiently large. ${ }^{172}$ Second, the government can offer monetary awards for whistleblowing to employees who otherwise would have been willing to collude in the firm's tax evasion. ${ }^{173} \mathrm{KKS}$ in effect offer an analog of the Allingham and Sandmo model for firms: the probability of detection of evasive behavior crucially depends not on audits conducted by the government, but on disgruntled employees or whistleblowers.

Unfortunately, this account of firms' tax compliance decisions is just as problematic as the traditional account of individual tax compliance decisions. To begin, although whistleblower programs operated by tax and other regulatory agencies have attracted attention in recent years, their role in the history of tax and other areas of regulatory enforcement has been minimal. ${ }^{174}$ Even today, whistleblower programs are viewed as

170. KKS, supra note 3. Another strand of the recent literature claims that firms do not cheat because they are subject to information reporting by other firms, for example through mechanisms under the VAT. See Carrillo et al., supra note 11, at 14; Pomeranz, supra note 9 , at 2541 (arguing that firms report honestly due to information reporting requirements). I have argued elsewhere that this strand of analysis involves mischaracterizations of and implausible claims about the VAT. Wei Cui, Information Reporting and State Capacity, paper presented at Part III of the 109th Annual Conference of the National Tax Association (Nov. 10, 2016).

171. KKS, supra note 3, at 220.

172. Id. KKS does not provide any simulation to specify how many employees a firm needs to have for evasion to be infeasible.

173. Id.

174. See, e.g., Peter J. Henning, Whistle-Blowing Insiders: 'Game Changer' for the S.E.C., N.Y. TIMES (Sept. 6, 2016), https://www.nytimes.com/2016/09/07/business/dealbo ok/whistle-blowing-insiders-game-changer-for-the-sec.html [https://perma.cc/J476-QED9] (discussing a whistleblower program that was only recently adopted by the U.S. Securities 
complements to regulatory agencies' audit operations, allowing the government to discover violations that would otherwise be difficult to uncover, ${ }^{175}$ rather than as a mechanism imposing more systematic constraints on taxpayers and other regulated subjects than audits themselves. It is simply implausible to claim that whistleblower programs undergird the transformation of public finance in the twentieth century witnessed in most advanced economies. ${ }^{176}$ Moreover, while it is commonly observed that larger firms tend to be more compliant with tax law and other legal requirements, firm size in itself does not preclude fraudulent activity: recent reports of large-scale frauds at Volkswagen and Wells Fargo offer vivid reminders of this fact. ${ }^{177}$

In the (vast) legal and social scientific literature on tax compliance, ${ }^{178}$ the inadequacy of the Allingham and Sandmo model has led to a variety of theories about why individuals may be motivated to follow the tax law. ${ }^{179}$ It is not the intention of this Article to review or even summarize this variety of theories. ${ }^{180}$ I will instead note two features of the

and Exchange Commission); Laura Saunders, How to Turn In Your Neighbor to the IRS, WALL ST. J. (Sept. 3, 2011), http://www.wsj.com/articles/SB100014240531119033527045 76540840395329676 [https://perma.cc/85SR-HH5F] (quoting tax historian Joseph Thorndike as reporting that payments to whistleblowers in the history of U.S. taxation "tended to be small and rare because IRS officials were uncomfortable with 'bounty hunting"'); Jordan A. Thomas, Policing the Banks Is an Inside Job, N.Y. TiMES (Sept. 30, 2016), https://www.nyti mes.com/2016/10/01/opinion/policing-the-banks-is-an-inside-job.html

[https://perma.cc/8W79-LAAW] (advocating the adoption of a whistleblower program by banking regulators).

175. See Henning, supra note 174 (noting, for example, that rewards for whistleblowers are increased in areas of agency priority).

176. See supra Part I, Figure 2.

177. Adam Davidson, How Regulation Failed with Wells Fargo, THE NeW YorKeR (Sept. 12, 2016), http://www.newyorker.com/business/currency/the-record-fine-against-wellsfargo-points-to-the-failure-of-regulation [https://perma.cc/R2VT-PEM2]; Russell Hotten, Volkswagen: The scandal explained, BBC NEws (Dec. 10, 2015), http://www.bbc.com/news/ business-34324772 [https://perma.cc/2RAG-TDE4].

178. See Slemrod, supra note 11 for a review of recent scholarship. For earlier reviews, see Andreoni et al., supra note 165; Lars P. Feld \& Bruno S. Frey, Tax Compliance as the Result of a Psychological Tax Contract: The Role of Incentives and Responsive Regulation, 29 LAW \& POL'Y 102, 102 (2007) (exploring tax compliance in terms of a psychological tax contract between citizens and the government); Slemrod \& Yitzhaki, supra note 165.

179. The inadequacy of the deterrence theory of compliance in other areas of publiclyenforced law has led to similar explorations in alternative theories. See, e.g., Michael P. Vandenbergh, Beyond Elegance: A Testable Typology of Social Norms in Corporate Environmental Compliance, 22 STAN. ENVTL. L.J. 55, 60 (2003) ("In the academic literature and policy debates, an alternative 'cooperation model' has been proposed, in large part as a reaction to the adversarial enforcement methods suggested by the deterrence model.").

180. A relatively recent summary and set of references can be found in Alex Raskolnikov, Revealing Choices: Using Taxpayer Choice to Target Tax Enforcement, 109 ColuM. L. REV. 
literature. First, theories that are presented as major alternatives to the Allingham and Sandmo model tend to postulate psychological features of individuals that are not captured by that model. ${ }^{181}$ However, to my knowledge, none has attempted to "put firms into [the theory]" in the way that scholars (such as KKS) aiming to salvage or expand the Allingham and Sandmo model have done. In other words, only scholars interested in reformulating the Allingham and Sandmo model have given significance to the regular empirical association between the presence of business firms and higher levels of tax compliance. Yet as Part I discussed, such empirical regularity seems unmistakable and forms part of the conventional wisdom of what makes tax administration effective. Of course, conventional wisdoms may be mistaken (as I have argued is the case for the belief about the importance of TPIR), but they may also be robust and offer important theoretical insights.

Second, many scholars have formulated theories and empirically tested hypotheses about tax compliance as though tax compliance is a selfcontained social problem. ${ }^{182}$ Although some legal scholars have argued that people comply with the tax law simply because there is a social norm of complying with the law, this approach is not generally followed. ${ }^{183}$ Instead, scholars tend to study individual preferences and attitudes specifically towards tax compliance, as if paying tax has become a deep-rooted part of our psyche. ${ }^{184}$ Yet modern taxation directly affecting the obligations of mass

689, 696-701 (2009). Another recent literature review can be found in Erzo F.P. Luttmer \& Monica Singhal, Tax Morale, 28 J. ECON. PERSP.. 149 (2014).

181. See, e.g., Frank A. Cowell, Cheating the Government: The Economics of EVASION 102-03 (1990) (finding that taxpayers' perceptions of other taxpayers in the same social grouping affect taxpaying attitudes and behaviors); Harold G. Grasmick \& Robert J. Bursik, Jr., Conscience, Significant Others, and Rational Choice: Extending the Deterrence Model, 24 LAW \& SOC'Y REV. 837, 847 (1990) (showing that the effect of the feeling of guilt or shame on tax cheating deterrence is greater than the effect of legal sanctions); Harold G. Grasmick \& Wilbur J. Scott, Tax Evasion and Mechanisms of Social Control: A Comparison with Grand and Petty Theft, 2 J. ECON. PsychOL. 213, 223 (1982) (showing that feelings of guilt have a greater effect on tax evasion deterrence than the threat of legal sanctions).

182. See, e.g, ERICH KIrChler, EconOmic Psychology of TAX BehaViour (2007); Erik Hoelzl et al., Enforced versus voluntary tax compliance: The "slippery slope" framework, 29 J. ECON. PSYCHOL. 210 (2008); Erich Kirchler, The art of dodging, FINANCIAL WORLD (JuneJuly 2015), at 43 (putting forth theories that treat tax compliance as a contained social problem).

183. See Eric Posner, Law and Social Norms: The Case of Tax Compliance, 86 VA. L. REV. 1781 (2000) (discussing tax compliance through the lens of the signaling model and social norms).

184. See, e.g., Andreoni et al., supra note 165; Grasmick \& Bursik, supra note 181; Grasmick \& Scott, supra note 181; James Alm \& Benno Torgler, Culture Differences and Tax Morale in the United States and in Europe, 27 J. ECON. PSYCHOL. 224 (2006) (discussing tax compliance in terms of a country's "tax morale"); Michael R. Welch et al., "But Everybody Does It . . .": The Effects of Perceptions, Moral Pressures, and Informal Sanctions 
populations of individuals has been practiced in most countries for barely a century. ${ }^{185}$

These features of the existing literature imply that existing theories of tax compliance may have neglected two institutional foundations of modern tax collection. The first is the business firm, which performs most of the compliance obligations under all modern taxes. ${ }^{186}$ Ironically, those scholars who have stressed the business firm's significance in tax compliance have at the same time conceived of it in such as a way (i.e., as a mechanical information depository and transmission device) as to give it very limited explanatory power. ${ }^{187}$ The second is the modern legal system, as embodied by institutions that play legislative, regulatory, enforcement, and adjudicatory functions, and as animated by the social norm of compliance with the law. The key to understanding tax compliance may precisely lie in understanding how individual behavior is mediated by these two types of institutions. I now describe how such an explanation would work.

\section{FIRMS AS SITES OF SOCIAL COOPERATION ORDERED BY LAW}

Consider the postulate that in modern (i.e., industrial and postindustrial) economies, most business firms operate, for the most part, in compliance with the law. If this is true, then an important social scientific question will be why it is true - what has brought about this state of affairs. But let me clarify first what the postulate means and what follows from it, if it is true.

The claim that most modern business firms mostly comply with the law is meant to convey the following two ideas. First, most firms operate in ways that are constrained by a wide range of legal rules and norms. That is, a firm makes its decisions while heeding most of the requirements of contract law, tort law, property (including intellectual property) law, and other relevant bodies of private law. It also attends to the relevant requirements of various bodies of regulatory law, such as those regarding public and workplace safety, labor and employment, environmental protection, financial prudence and disclosure, and so on. This does not mean that the firm is necessarily perfectly compliant with the law. Far from it. Volkswagen may systematically install illegal "defeat devices" in its diesel engines to dodge the Environmental Protection Agency's emission tests. ${ }^{188}$

on Tax Cheating, 25 Soc. SPECTRUM 21, 29 (2005) ("[S]tudies have examined the effects of moral obligation on taxpayer compliance.").

185. KKS, supra note 3, at 225 (Figure 2).

186. See supra Parts I-II.

187. Kopczuk \& Slemrod, supra note 39.

188. Hotten, supra note 177. 
But this could happen while the company at the same time conscientiously follows all kinds of other legal requirements imposed by Germany and the United States. Wells Fargo may put intense pressure on retail branch employees to meet sales targets, knowing that this had led to and would continue to lead to the creation of fake customer accounts, but the bank meanwhile could very well be highly compliant in its tax and securities filings. ${ }^{189}$ In other words, for many firms that purposely engage in one type of illegal behavior or another, they nonetheless are acting in compliance with a wide range of other applicable laws. They do not cheat "wherever they can," in the sense of exploiting every opportunity to earn an expected profit by violating the law.

Second, while some business firms may be better behaved than Volkswagen and Wells Fargo, others are of course more ill-behaved. Some firms act in dodgy ways in respect of many legal requirements. But it may be plausible to classify these firms into several categories. To begin, there are the very small firms - indeed in economists' use of the term, a "firm" could be a sole business proprietor. A small firm's behavior would not be distinguishable from the behavior of its few individual owners or employees, and there is little intra-firm organization or coordination. Alternatively, a frequently law-dodging firm could be large, but we expect it to be one that is otherwise uncompetitive in the market it operates: it needs to cheat wherever possible just to survive. ${ }^{190}$ Finally, there are of course firms that are formed deliberately to commit fraud or other crimes. However, putting this last type of firm aside, and even considering small firms and firms under intense competitive pressure and the fact that these firms are more likely to act in disregard of the law than others, the following seems to be true: few firms are organized with the expectation that it would deliberately profit from the violation of all laws that are profitable to violate, and few firms grow and remain competitive by profiting from illegal activities. This is what I mean by the claim that most modern business firms mostly comply with the law.

Having explained the meaning of the claim, I now explain one crucial consequence of it. The claim implies that most modern business firms would not make decisions about tax compliance in the way that KKS' model suggests: they do not decide to comply with the tax law only when an internal collusive bargain about how to divide the spoils of tax evasion cannot be sustained. Instead, complying with the tax law, like complying

189. Davidson, supra note 177.

190. See Hongbin Cai \& Qiao Liu, Competition and Corporate Tax Avoidance: Evidence from Chinese Industrial Firms, 119 ECON. J. (LonDON) 764 (2009) (arguing that market competition increases incentives for Chinese firms to engage in tax avoidance activities); Andrei Shleifer, Does Competition Destroy Ethical Behavior? 94 AM. ECON. REV. 414 (2004) (illustrating how unethical conduct can be a consequence of market competition). 
with other bodies of laws, is the default option. If a firm is generally compliant with the law, then compliance with the tax law should simply be expected. Specific firms may be engaged in non-compliance with the tax law at specific times, but such behavior is to be explained in the same way as one would want to explain why Volkswagen decided to install its "defeat devices," and why Wells Fargo pushed its employees towards fraudulent practices. In other words, when the baseline expectation is compliance, specific instances of non-compliance are what require explanation, not the multitude of instances of compliance.

Here, it should be noted that KKS' model has a common structure with the Allingham and Sandmo model of individual tax compliance: the taxpayer, whether a firm or an individual, always confronts a meaningful choice between complying and not complying with tax law, and it would choose to comply only when the expected penalty for non-compliance is large enough. ${ }^{191}$ Moreover, this choice is conceived in a way that could characterize choices about whether to comply with any other body of law: as long as the expected rewards of non-compliance outweigh the expected punishment of non-compliance, non-compliance should be observed. The empirical postulate above about modern business firms' general tendency towards law compliance precisely contradicts the premise of these theoretical models. ${ }^{192}$ It claims instead that modern business firms are generally law-abiding, or at least enough of them are for tax and other regulatory systems generally to function.

However, making this postulate is not the end, but only the beginning, of social scientific inquiries. The important social scientific

191. KKS, supra note 3, at 229 (Proposition 2).

192. There is an obvious analogue of this objection to the KKS model for the Allingham and Sandmo model. The latter model is famously inspired by Gary Becker's economic model of crime: when Allingham and Sandmo conceptualize an individual taxpayer's compliance decision, they portray the person in a way similar to a criminal weighing the costs and benefits of a crime. Gary Becker, Crime and Punishment: An Economic Approach, 76 J. Pol. Econ. 169 (1968). However, Becker did not set out to explain why ordinary people do not commit crime by his economic model: his economic theory of deterrence is intended only to apply to criminals. Allingham \& Sandmo, on the other hand, conflate the ordinary taxpayer deciding what to enter on his tax return and a criminally-minded person ready to cheat on his taxes where possible. Allingham and Sandmo, supra note 162, at 323 (citing studies of the economics of criminal activity as relevant to "the individual taxpayer's decision on whether and to what extent to avoid taxes by deliberate underreporting[,]" implying the irrelevance of the distinction between a typical taxpayer and a criminal). That is to say, they elide the distinction between the ordinary person and the criminal in depicting the rational choice about tax compliance. Id. Whether this is a plausible depiction of the average taxpayer's psychology is controversial. Those who favor the Allingham and Sandmo model presumably find the characterization more (or at least no less) plausible than representations of the average taxpayer as pro-social, conscientiously law-abiding, and simply oblivious to the potential rewards of cheating. The argument I make in this Part does not require one to take a position directly on this controversy. 
question is not why, given the default choice of cheating, most (large) firms don't cheat on their taxes. It is rather why these firms may not even consider cheating on their taxes - why cheating is not their default choice. A number of theoretical and historical considerations suggest that there may be genuine answers to this question, and that it does not just offer a rhetorical reformulation of the seemingly intractable controversy about what produces compliance on the part of individual taxpayers.

The first theoretical consideration is that firms generally form in order to earn some economic rent. ${ }^{193}$ If there is no economic rent to be made, one can simply purchase and sell in the market and there is no need to form a firm. ${ }^{194}$ However, if firms are generally formed with the purpose of earning rent given market prices, then there is no need for firms already formed to further exploit profits from violations of the law. It is true that some illegal activities can be conducted only through firms (e.g., certain Ponzi schemes, VAT carousal fraud, etc.). ${ }^{195}$ But it is also the case that most illegal activities can be pursued without forming firms. Therefore, if a firm is formed not in order to profit from illegal activities, but with the purpose of earning rents from other identified opportunities, then it would not be surprising if the firm does not maximally exploit opportunities arising from illegal behavior; that is simply not its purpose.

193. See generally G.C. Archibald, Theory of the firm, in THE NEW PALGRAVE DiCTIONARY OF ECONOMICS (Lawrence Blume \& Steven Durlauf eds., 2d ed. 2005) (reviewing theories of the firm and the role of quasi-rent in such theories); Oliver. E. WiLliamson, ThE MeCHANISMS OF GOVERNANCE (1996) (illustrating that firms are distinguished by firmspecific assets that generate quasi-rent); Oliver D. Hart, An Economist's Perspective on the Theory of the Firm, 89 Colum. L. REV. 1757 (1989) (providing an overview of how economists think about firms); Oliver D. Hart, Incomplete Contracts and the Theory of the Firm, 4 J. L. ECON. \& ORG. 119 (1988) (proposing that a firm can be thought of as arising out of the incompleteness of contracts); D. Bruce Johnsen, The Quasi-Rent Structure of Corporate Enterprise: A Transaction Cost Theory, 44 EMORY L. J. 1277 (1995) (asserting that corporate financial claims can reveal the net value of a firm in alternative uses); Benjamin Klein et al., Vertical Integration, Appropriable Rents, and the Competitive Contracting Process, $21 \mathrm{~J}$. LAW ECON. 297 (1978) (considering the economic costs of forming a firm); Joseph T. Mahoney \& Lihong Qian, Market Frictions as Building Blocks of An Organizational Economics Approach to Strategic Management, 34 STRAT. MGMT. J. 1019 (2013) (using a theory of rent-generating market frictions to explain the existence of the firm); Oliver E. Williamson, Examining economic organization through the lens of contract, 12 IND. CORP. CHANGE 917 (2003) (examining firms from the perspective of transaction cost economics).

194. Ronald H. Coase, The Nature of the Firm, 4 ECONOMICA 386 (1937) (explaining that firms form to reduce transaction cost and earn profit that could not be earned through market transactions).

195. See, e.g., Gianluca Fiorentini \& Sam Peltzman (Eds.), The Economics of Organized CRIME (1995) Vimal Kumar \& Stergios Skaperdas, On the Economics of Organized Crime (University of California-Irvine, Department of Economics, Working Papers No. 70815, 2008), http://www.economics.uci.edu/files/docs/workingpapers/200708/skaperdas-15.pdf [https://perma.cc/TRX8-XR5Z] (giving background about the structure of organized crime organizations); 
A second consideration, which is both theoretical and historical in nature, is that much of the modern legal system is concerned with how to divide up the rent earned by firms among the contributors to the firm employees, lenders, equity investors, suppliers and customers. ${ }^{196}$ This is what corporate and other organizational law is about. ${ }^{197}$ It also forms an important part of the substance of employment, labor and securities law. That is to say, social cooperation that is centered on a firm inherently presupposes ways of dividing up the surplus from cooperation, and the legal system appears to have been deeply involved in facilitating this division and thus enabling firm-centered cooperation. Therefore, firm-centered social cooperation is a paradigmatic form of "legal order" - social cooperation mediated by legal norms. ${ }^{198}$

A recent study by Suresh Naidu and Noam Yuchtman of nineteenth century labor market institutions in the United States vividly illustrates this consideration. ${ }^{199}$ Naidu and Yuchtman examine a part of U.S. history (1850 until the early 1920s) when labor markets were still largely unregulated. ${ }^{200}$ They first show that firm-specific rents were frequently observed in urban American labor markets: when firms experienced positive output price shocks, their employees earned wage premia, relative to other employees with very similar skills in the same urban labor market. ${ }^{201}$ They then argue that the existence of rents in the labor contract created space for bargaining and conflict between employees and employers: strikes became sharply more frequent in the late nineteenth and early twentieth centuries, often involved physical coercion against replacement workers, and were correlated with higher workers' wages. ${ }^{202}$ On their side, employers occasionally called in the police and military to break strikes, but more frequently and equally effectively sought judicial injunctions to end strikes. ${ }^{203}$ In other words, even before the advent of labor and employment regulations, both the coercive

196. See, e.g., Masahiko Aoki, The Co-Operative Game Theory of the Firm (1984) (modelling how managers facilitate cooperation game among capitalists and workers to achieve institutional rent).

197. Marco Becht et al., Corporate Law and Governance, in 2 HANDBOOK OF LAW AND ECONOMICs 829-943 (A. Mitchell Polinsky \& Steven Shavell, eds. 2007).

198. For the concept of a legal order as opposed to social cooperation governed by other types of social norms, see Gillian Hadfield \& Barry Weingast, Microfoundations of the Rule of Law, 17 ANN. Rev. Pol. SCI. 21 (2014).

199. Suresh Naidu \& Noam Yuchtman, Labor Market Institutions in the Gilded Age of American History (NBER Working Paper No. 22117, 2016).

200. Some European countries had already adopted labor regulations at the time. See, e.g., William E. Forbath, Courts, Constitutions, and Labor Politics in England and America: A Study of the Constitutive Power of Law, 16 \& .L SOC. INQUIRY 1, 22-25 (1991) (discussing the history and evolution of English labor law in the nineteenth and twentieth centuries).

201. Naidu \& Yuchtman, supra note 199, at 9-11.

202. Id. at 11-12.

203. Id. at 17-20. 
apparatus of the state and judicial institutions were called upon to resolve intra-firm conflicts. Subsequent labor and wage regulations that began to be adopted at the state level in the early twentieth century and at the federal level as a result of the New Deal are clearly more permanent legal institutions that allowed firm-centered social cooperation to continue. ${ }^{204}$

In other words, reliance on the legal system - and in particular on the regulatory apparatus of the state - may be essential to the growth of the modern business firm as we know it. Compliance with legal rules and norms, and monitoring the compliance of other parties, are intrinsic aspects of the modern business firm as an institution. From this perspective, the basic reason that large firms are more likely to be compliant is not that the probability of motivated whistleblowers is higher in them (or that they have greater external visibility). The potentially more important reason is that the firms grew larger because they were profitable, and the participants in them are more interested in the orderly division of profits than the disorder implied by cheating (on taxes and other regulatory matters). While the keeping of business records and proper accounting practices form a part of this cooperative process, their main benefit for tax compliance may arise not from facilitating effective audits by the government, but from the fact that they allow participants in a firm to monitor one another in assessing whether the expectation of fair divisions of profits is fulfilled.

This conjecture seems consistent with the history of modern taxation in different industrial economies. In the United States, for example, the adoption of the "mass income tax" began in 1939 and the withholding of income tax on wage payments - the administrative institution that scholars previously focused on — began in $1943 .^{205}$ Both were pre-dated by the adoption of withholding of Social Security taxes in $1935 .^{206}$ To track the roots of income tax compliance in the United States, therefore, one needs to explain why business firms complied with the Social Security excise on employers and with the even earlier legal requirements (enacted in 1909) to pay corporate income taxes. ${ }^{207}$ Previous tax legal scholarship has suggested that the corporate income tax was conceived from the beginning as at least in part a device for regulating large U.S. corporations, and this regulatory impulse was also manifest in corporate and antitrust law developments at the same time. ${ }^{208}$ But just as relevantly, corporations and employers in general

204. Id. at 20 .

205. Desai, supra note 16 , at 865,896 . Notably, the previous version of wage withholding, introduced in 1860 , involved the withholding only by the federal government as employer, not by business firms. Id.

206. Id. at 889-96.

207. Id. at 882 .

208. See, e.g., Reuven Avi-Yonah, Corporations, Society, and the State: A Defense of the Corporate Tax, 90 VA. L. REV. 1193 (2004) (describing the origins of the corporate income 
had already been subject to other forms of regulation to facilitate the formation of American financial and labor markets. ${ }^{209}$ By the time the corporate income tax was put in place, whether to comply with the law was presumably neither a new question nor one that businesses could easily give a negative answer to if they were to continue to operate at all

In summary, it seems that as a matter of actual history, two interrelated institutions might have represented the central components of the foundation of modern tax collection. The first is the business firm. The second is the set of legal rules and norms that developed from the eighteenth to the twentieth century that accompanied the growth of the corporate form: organizational law, antitrust and securities regulation, and labor and employment law, in addition to the ever-present bodies of contract, property, tort, and other private law. Because the operation of most business firms was inseparable from the implementation and following of legal orders, the decision to comply with the tax law was a natural one for firms to make. Upon these foundations, both business taxes and taxes imposed on individuals but remitted by businesses evolved, with withholding, third-party reporting, other administrative devices, and legal doctrines that guide the use of such devices all emerging simultaneously. Self-reporting, audits, and other methods of enforcing the tax law were always important to tax collection, just as they were important in securing compliance with other types of law applicable to firms. But most firms in most circumstances may also have displayed a substantial degree of voluntary compliance, insofar as the laws they followed enabled social cooperation in the context of the firm in the first place

Three features distinguish the foregoing account of modern tax compliance from previous accounts. First, the explanation is institutional: it refers to specific institutions, social practices, and legal norms. By contrast, much of the social scientific literature on tax compliance, like the Allingham and Sandmo model, is psychological and predicts social behavior from assumptions about individual psychology (the only institutions assumed are tax return filing, auditing and the imposition of penalties). The benefit of the institutional approach is that it allows us to focus on explaining why rational, self-interested individuals may engage in cooperation in

tax, particularly the regulatory rationale behind its conception); Steven A. Bank, Entity Theory as Myth in the Origins of the Corporate Income Tax, 43 WM. \& MARY L. REV. 447, 449 (2001) (dating the "dual system of business taxation in which corporations and partnerships receive disparate treatment" back over a century).

209. Mark Aldrich, History of Workplace Safety in the United States, in EH.NET ENCYCLOPEDIA OF ECONOMICS AND BUSINESS HISTORY (Robert Whaples ed., 2001), http://eh.net/encyclopedia/history-of-workplace-safety-in-the-united-states-1880-1970/

[https://perma.cc/CT4Q-G7EM]. 
specific contexts, instead of explaining why they are generally willing to cooperate.

Second, while other scholars have also emphasized the importance of the firm as a crucial institutional component of modern tax compliance, under the account given here, there is much more going on in firms that is potentially of interest to tax auditors than just the keeping of business records and accounting books. Instead, firms are places where members of society actively cooperate under regimes of law. Instead of gaming the system where they can, individuals pursue profit and bargain for rent within the confines of law. This approach has strong support from economic theories of the firm, ${ }^{210}$ and allows the psychological theories of compliance to be enriched by the theoretic and empirical literature in organizational economics.

Third, the account captures the intuition of many that there is nothing special about tax compliance per se, vis-à-vis compliance with other aspects of the law; it should be explainable by the same motivations. However, instead of postulating general pro-social, norms-respecting motivations for individual taxpayers, the account suggests that they will be motivated to act this way, in respect to many types of law, in the context of the firm. It is worth noting here that using TPIR to explain modern tax compliance would provide one with no purchase in explaining most other types of compliance with the law. As suggested above, the conception of business firms as passive and mechanical depositories and transmission devices for taxpayer information has no analogue in other literature. ${ }^{211}$ Seeing business firms as institutions within which individuals can cooperate in an indefinite range of ways while being regulated by an indefinite range of legal norms, by contrast, not only constitutes a generalizable theory of tax compliance but also gives such theory greater plausibility.

\section{POLICY IMPLICATIONS}

Understanding the institutional foundations of modern taxation has deep policy implications both for developing countries aiming to enhance their state capacity ${ }^{212}$ and for developed countries like the United States aiming to improve tax compliance. ${ }^{213}$ This Part offers a preliminary discussion of how the perspective developed in the preceding Parts suggests

210. See supra notes 193-97.

211. See, e.g., Vandenbergh, supra note 179 (attempting to draw analogies between tax compliance and compliance with environmental regulations, in which third-party information reporting plays no role).

212. See supra notes 1-7 and accompanying text.

213. See supra notes $15-22$ and accompanying text. 
policy directions different from what scholarship focused on TPIR would recommend.

\section{A. Implications for Developing Countries}

There is no doubt that in any country, when the level of tax compliance is low, tax collectors thirst for taxpayer information. It is thus hard to overstate the appeal to developing countries of the notion that hightax, advanced economies have designed institutions for transmitting and making use of massive amounts of taxpayer information. If such information gathering devices can be adopted, they would be effective substitutes for voluntary compliance. Taxpayers would have no choice but to obey the law. ${ }^{214}$ A technological approach to tax administration would then help many poor countries overcome the weaknesses of their institutions.

As much as recent scholarship on TPIR has encouraged this notion, ${ }^{215}$ this Article has argued that it is fundamentally untenable. Promoting the forms of TPIR that are commonly adopted in developed economies is unlikely to dramatically enhance tax administration capacity in developing countries for the following reasons. First, the standard forms of TPIR adopted by developed countries apply to the collection of the personal income tax on wage and passive financial income. ${ }^{216}$ But all available evidence suggests that developing countries already deploy similar administrative devices - especially withholding - for such tax bases. For example, Leslie Robinson and Joel Slemrod examined whether developing countries use information reporting or withholding less than developed countries by systematically coding comparative information about tax administration published by the OECD. ${ }^{217}$ They analyzed, for each of 47 countries: (1) the total number of income categories for which tax is withheld and remitted by the payer; (2) the total number of categories of income that are subject to information reporting; and (3) the extent to which taxpayer identification numbers (TINs) are used as measured by the total number of payment types that use TINs. ${ }^{218}$ It turns out that all of these variables are negatively correlated with a country's GDP per capita: the poorer countries use withholding, information reporting, and identity-matching more than the

214. Kleven et al., supra note 11, at 689-691.

215. See supra notes 9-14, 34-41 and accompanying text.

216. See supra Part I.

217. Leslie Robinson \& Joel Slemrod, Understanding Multidimensional Tax Systems, 19 INT'L TAX PUB. FIN. 237 (2012). The comparative information covers 30 OECD and 17 nonOECD countries for the year 2005. The 17 non-OECD countries include, among others, Brazil, India, China, Malaysia, Russia, and South Africa.

218. Robinson \& Slemrod, supra note 217, at 243. 
wealthier countries. ${ }^{219}$ They thus observe: "In higher-income countries, the revenue body uses withholding and reporting on fewer types of income."220 Similar studies done by the IMF also suggest that many developing countries heavily rely on withholding. ${ }^{221}$

It is thus very unlikely that developing countries are not attuned to the wide use of withholding and TPIR for the personal income tax in developed countries. Instead, the problem is much more likely that they have far smaller tax bases comprising wage and passive financial income: their formal employment sectors and financial institutions are more underdeveloped. ${ }^{222}$ The important question is then whether TPIR has proven to be useful in the experience of developed countries, outside the context of these particular components of the personal income tax. As Parts I-III have shown, the answer is no. TPIR has had only limited application in the individual business income context, ${ }^{223}$ and its utility for increasing compliance in such a context is still open to debate. ${ }^{224}$ Moreover, such limitation may have universal explanations (e.g., in terms of when market participants keep mutual identities) invariant to developmental contexts. ${ }^{225}$ In addition, developed countries rarely use TPIR in connection with other important modern taxes. ${ }^{226}$ It would clearly be a mistake to infer - from the fact that

219. Id. at 251. Robinson and Slemrod also use factor analysis to construct a single variable that summarizes tax administration features of a country, which they label "Dispersed Responsibility" and which they view as capturing "the extent to which the tax collection system disperses responsibility and the direct compliance burden away from the tax authority to the taxpayer and third parties such as employer withholders." The same negative correlation with GDP per capita obtains for this variable. Id. at 249.

220. Id. at 251. Robinson and Slemrod only analyze income tax administration. The wide adoption of the VAT, and the dominance of VAT revenue over not only personal but also corporate income tax revenue in many developing countries, would further strengthen the quoted observation. See INT'L MONETARY FUnd, supra note 2.

221. See, e.g., INT'L Monetary FUnd, Revenue Mobilization in Developing Countries 31 (prepared by Fiscal Affairs Dept.) (Mar. 2011), https://www.imf.org/external/np/pp/eng/2011 /030811.pdf [https://perma.cc/DG97-RSG3] (finding receipts from the personal income tax in developing countries come almost entirely from wage withholding on large enterprises and public sector employees); see also id. at 41 (noting advance collection on imports is common in Africa).

222. See Gordon \& Li, supra note 45 (hypothesizing that low levels of financial development substantially determine the tax structures of developing countries); Jensen, supra note 44 (showing limited size of formal employment sectors in developing countries). See also discussion supra Part II.D.

223. See supra Part III.A-B.

224. See supra Part III.C.

225. See supra Part III.B. See also Carrillo et al., supra note 11 (arguing that in developing countries, TPIR may be ineffective due to its incompleteness and because taxpayers can always evade on the margins where government verification is difficult; Carrillo et al. thereby imply that this is not the case in developed countries, which is incorrect).

226. See supra Part I. 
wage and personal financial income constitute larger tax bases in developed countries - that developed countries use TPIR in a wider variety of ways than (or in substantively different ways from) developing countries. ${ }^{227}$

As argued earlier, developed countries to a very large extent rely on businesses to withhold, remit, and pay most taxes. ${ }^{228}$ Voluntary business compliance lies at the foundation of TPIR, not the other way around. ${ }^{229}$ When businesses comply with the tax law, the government can afford to be somewhat indifferent about whether information on individual taxpayers is collected or analyzed. Tax administrators from developing countries are in fact likely to be quite familiar with this logic. Developing countries generally rely far less on the personal income tax and social security contributions for revenue than developed countries; the corporate income tax, VAT, turnover taxes, and other business taxes collectively represent a much greater portion of the tax take. ${ }^{230}$ One could thus say that business firms are the main source of revenue for developing countries. What, then, differentiates between tax administrations in poorer and in richer countries - what, from the perspective of law enforcement and compliance, explains the striking difference among them captured by political economists? ? $^{231}$

This Article has suggested the following answer. The growth of business firms in developed countries has been closely intertwined with the regulatory state, in that the latter has played a crucial role in facilitating the division of economic profit within business firms. Within the institution of the modern firm, rational, self-interested individuals are able to engage profitably in a whole range of economic cooperation, in key part because they can rely on regulatory mechanisms to ensure that the benefits of cooperation are divided in ways that are bargained for. For this reason, participants in the firm are often willing to commit resources to compliance with regulations and the law in general. This dynamic has evolved to a point that firms generally do not consider non-compliance with tax law as their default option; after all, the tax law is generally enacted and enforced by the same governments that have enacted and enforced the other legal rules that are crucial to the cohesion of firms. What distinguishes richer and poor

227. Developing countries may make less use of TPIR, as opposed to withholding, insofar as their governments are less likely to make non-observable characteristics of taxpayers determinative of tax liabilities. See supra notes 80-83 and accompanying text.

228. See supra Part I.

229. See supra Part II.B.

230. Richard Bird \& Eric Zolt, Redistribution Via Taxation: The Limited Role of the Personal Income Tax in Developing Countries, 52 UCLA L. REV. 1627 (2005); Gordon \& Li, supra note 45.

231. See KKS, supra note 3 (modeling how TPIR by employers may sustain tax enforcement, despite low fines and audit rates, as economic development affects the structure of firms to promote verifiable book evidence and large numbers of employees). See also supra Figure 1. 
countries, therefore, is that in the former there are more firms that operate in this mode, both because of the greater development of markets and because of the deeper involvement of governments in sustaining these markets.

Such an analysis clearly implies that the effectiveness of tax administration depends on exogenous factors - factors that fall outside tax administrators' control. Improving tax administration must of necessity be viewed in a holistic manner. While information gathering and enforcement aimed at producing deterrence are always important, tax collection will also inevitably be a matter of relying on, contributing to, and, importantly, not disrupting social cooperation centered on business firms that are ordered by legal and regulatory systems. Deterrence cannot substitute for voluntary compliance. Therefore, one must be cautious about adopting any instrument of deterrence if it would undermine voluntary compliance. ${ }^{232}$ This provides new support to the idea that rule of law norms are important to tax administration. ${ }^{233}$

\section{B. Implications for the U.S. and Other Developed Countries}

Third-party information reporting, only to a slightly lesser extent than withholding, has become a deeply entrenched feature of personal income tax administration in the United States and other advanced economies. ${ }^{234}$ The expansion of TPIR in the U.S. to include broker reporting of the tax basis of securities and credit card and electronic settlements of merchants, ${ }^{235}$ although still largely unrivaled by other countries, is not altogether surprising. Not only do the costs of the new reporting requirements now seem acceptable and not overly onerous, the issuance of 1099-Ks and similar forms will likely be embraced by an ever-growing population of taxpayers, as the forms help taxpayers to keep clear records and thereby reduce compliance costs. ${ }^{236}$

232. Another way of putting this is that the chief lesson for tax administrators from the investigation of the institutional foundations of modern taxation is not so much about what to do as it is about what not to do.

233. See The Delicate Balance: Tax, Discretion and the Rule of LaW (Chris Evans, Judith Freedman, et al. eds., 2011) (exploring the tension between the necessary discretionary power of tax administration authorities and the rights of taxpayers to have that power governed by the rule of law); Wei Cui, Administrative Decentralization and Tax Compliance: A Transactional Cost Perspective, 65 U. TORONTO L.J. 186 (2015) (providing an account of how tax collection may proceed in the absence of voluntary compliance and the distortions to tax policy this generates).

234. See generally RetURn-Free Systems, supra note 65 (providing a comparative review of the practice of final withholding on wage income and financial income).

235. See supra notes 18-20.

236. See Oei \& Ring, supra note 18 (making recommendations for more effective tax administration and compliance incentives for gig economy workers based on studying the tax 
None of the arguments in this Article are meant to suggest that the U.S. should roll back any specific type of TPIR that it currently adopts, or to deny that TPIR may have assorted benefits for taxpayers. Nor do I advocate against any specific way of expanding the scope of TPIR. If the arguments in Part III.B are correct, there are likely to be natural limits of TPIR, expansion beyond which may generate substantial jumps in compliance costs. But the magnitude of such costs will clearly depend on the technologies available. If, for example, few American consumers and businesses use cash or even credit cards in the future, but instead rely on newer technologies (such as Blockchain) to execute payments, it may be that even instantaneous transactions will begin to leave digital trails that would identify the transacting parties and the amount and nature of transactions. Should the IRS want to collect such information to limit under-reporting of business income by self-employed individuals, it would probably be able to do so more easily (and with less political resistance) than today.

But such speculations about how future technology might reduce tax evasion are misguided, for at least two (related) reasons. First, it is highly likely that new technologies will transform markets and economies, leading to substantial changes in the tax policy instruments that societies adopt. In other words, the main tax bases in future economies will likely be different from the tax bases today. ${ }^{237}$ To imagine how future technology might solve tax administration problems that exist only relative to the tax bases we have today is an odd form of futuristic exercise. Second, unless technology by itself could guarantee large-scale social cooperation, it seems implausible to imagine that in future societies there will not be criminals, free-riders, and norm violators. Presumably, technologies are developed to enable most cooperative humans to reap greater cooperative gains. They are not designed to make non-cooperation impossible. Therefore, criminal and free-riders will find new ways to cheat, and it will be completely irrelevant that they cannot cheat by exactly the same means as they do today.

Overall, that is, tax administration in the future (for those who care to think about it) will depend on a wide range of social institutions and circumstances, just as, as this Article has argued, twentieth century taxation has relied on the business firm and modern regulatory law. To improve tax administration today, one needs to better understand what the most relevant factors determining compliance are today. This Article has suggested a direction in which to look that is very different from prior scholarship.

issues and challenges encountered by ridesharing service drivers).

237. As some obvious examples: capital gains taxation may be replaced by mark-tomarket income taxation. Better information about behavioral patterns of individuals may also lead to new forms of excise taxation. 


\section{CONCLUSION}

The arguments of this Article aim to enable one to see how modern governments can practice "taxation without information." 238 This is exactly the opposite of what some recent political economy scholarship (and much conventional wisdom within legal scholarship) suggests to be the basic logic of modern taxation. ${ }^{239}$ With no institutional foundation, it may be true that there can be "no taxation without information." ${ }^{240}$ But modern taxation is not devoid of institutional foundation. The co-evolution of business firms and systems of regulatory law in industrial economies is likely to have laid very robust foundations for compliance with the law, which enabled the United States and many countries to quickly increase their levels of taxation in the twentieth century, sometimes within the space of a few years, ${ }^{241}$ at a time when modern computing technology was still at its infancy.

Modern taxation involves massive social cooperation: governments are put in place on the basis of systematic transfers of wealth. ${ }^{24}$ The deterrence model of tax compliance purports to explain taxpayers' participation in such social enterprise by how they might be punished for free-riding. ${ }^{243}$ If social cooperation in general can be explained simply by reference to how free-riders are deterred, the social sciences would be in a very different place from where they stand today. ${ }^{244}$ Conversely, if the emergence of social cooperation in human societies cannot be explained by simple detection and punishment mechanisms, it is not clear why government and taxation should constitute an exception. From this perspective, the Allingham and Sandmo theory of tax compliance is clearly inadequate, as is the insistence that recognizing the role of TPIR would salvage the Allingham and Sandmo model. But merely identifying psychological attitudes that characterize normal, compliant taxpayers in advanced economies also does not do justice to the historical, cross-country, and even within-country variations in the level of tax compliance. The understanding of tax compliance - and arguably of compliance with modern regulatory law in general - must be more firmly grounded in the understanding of a wider range of institutions.

238. KKS, supra note 3, at 225 (Figure 2).

239. See sources cited supra notes 12 and 16.

240. Pomeranz, supra note 9, at 2539.

241. KKS, supra note 3, at 225 (Figure 2); supra note 41.

242. See sources cited supra notes 2, 3 .

243. KKS, supra note 3; Allingham \& Sando, supra note 162.

244. See generally John E. Roemer, How we cooperate... perhaps (Apr. 2, 2015) (unpublished working paper, on file with Yale University) (providing a recent review of the social science literature on human cooperation). 